\section{oril}

OAK RIDGE

NATIONAL

LABORATORY
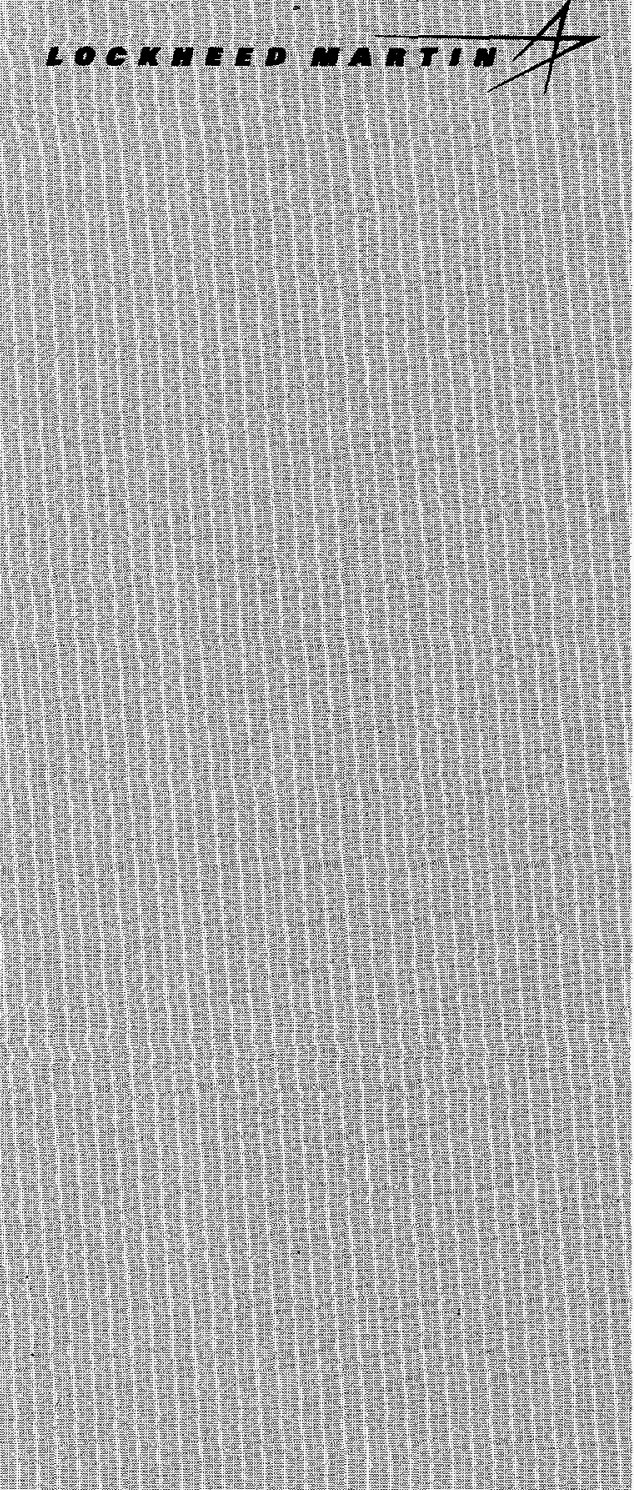

MANAGED AND OPERATED BY

LOCKHEEO WARTI ENERGY RESEARCH CORPORANON FOBTHE UNTED STATES

DEPARTIENT OF ENERGI

\section{JuL 15 . \\ $08 \mathrm{TI}$}

Advanced Neutron Source Reactor Conceptual Safety Analysis Report, Three-Element-Core Design: Chapter 15, Accident Analysis

\author{
N. C. J. Chen \\ M. W. Wendel \\ G. L. Yoder \\ R. M. Harrington
}

November 1995

(Date published: February 1996)

\section{MASTER}

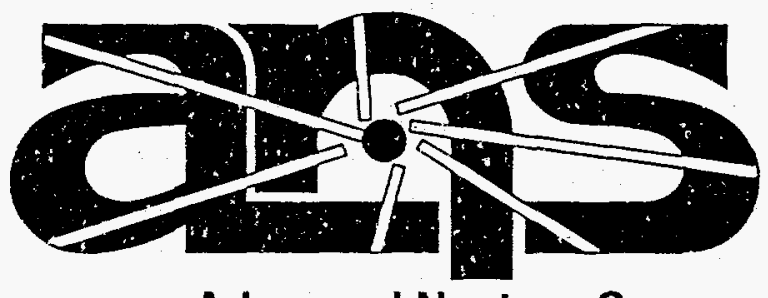

Advanced Neutron Source

DISTRIBUTION OF THIS DOCUMENT IS UNLIMITED 
This report has been reproduced directly from the best available copy:

Available to DOE and DOE contractors from the Office of Scientific and Technical Information, P.O. Box 62, Oak Ridge, TN 37831; prices available from (615) 576-8401, FTS 626-8401.

Available to the public from the National Technical Information Service, U.S. Department of Commerce, 5285 Port Royal Rd., Springfield, VA 22161.

This report was prepared as an account of work sponsored by an agency of the United States Government. Neither the United States Government nor any agency thereof, nor any of their employees, makes any warranty, express or implied, or assumes any legal liability or responsibility for the accuracy, completeness, or usefulness of any information, apparatus, product, or process disclosed, or represents that its use would not infringe privately owned rights. Reference herein to any specific commercial product, process, or service by trade name, trademark, manufacturer, or otherwise, does not necessarily constitute or imply its endorsement, recommendation, or favoring by the United States Government or any agency thereof. The views and opinions of authors expressed herein do not necessarily state or reflect those of the United States Government or any agency thereof. 
ORNL/TM-13077

ENGINEERING TECHNOLOGY DIVISION

\title{
ADVANCED NEUTRON SOURCE REACTOR CONCEPTUAL SAFETY ANALYSIS REPORT, THREE-ELEMENT-CORE DESIGN: CHAPTER 15, ACCIDENT ANALYSIS
}

\author{
N. C. J. Chen \\ M. W. Wendel* \\ G. L. Yoder \\ R. M. Harrington ${ }^{\dagger}$ \\ * Computational Physics and Engineering Division \\ $\dagger$ Central Managment Division
}

February 1996

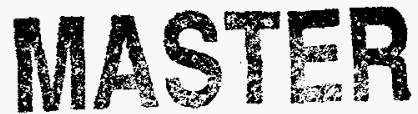

Prepared by the

OAK RIDGE NATIONAL LABORATORY

Oak Ridge, Tennessee 37831

managed by

LOCKHEED MARTIN ENERGY SYSTEMS, INC.

for the

U.S. DEPARTMENT OF ENERGY

under contract DE-AC05-96OR22464 



\section{DISCLAIMER}

This report was prepared as an account of work sponsored by an agency of the United States Government. Neither the United States Government nor any agency thereof, nor any of their employees, make any warranty, express or implied, or assumes any legal liability or responsibility for the accuracy, completeness, or usefulness of any information, apparatus, product, or process disclosed, or represents that its use would not infringe privately owned rights. Reference herein to any specific commercial product, process, or service by trade name, trademark, manufacturer, or otherwise does not necessarily constitute or imply its endorsement, recommendation, or favoring by the United States Government or any agency thereof. The views and opinions of authors expressed herein do not necessarily state or reflect those of the United States Government or any agency thereof. 


\section{DISCLAMMER}

Portions of this document may be illegible in electronic image products. Images are produced from the best available original document. 
LIST OF FIGURES $\ldots \ldots \ldots \ldots \ldots \ldots \ldots \ldots \ldots \ldots \ldots \ldots \ldots \ldots \ldots \ldots \ldots$

LIST OF TABLES $\ldots \ldots \ldots \ldots \ldots \ldots \ldots \ldots \ldots \ldots \ldots \ldots \ldots \ldots \ldots \ldots \ldots \ldots \ldots \ldots$

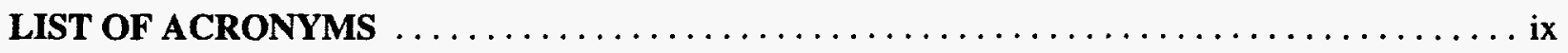

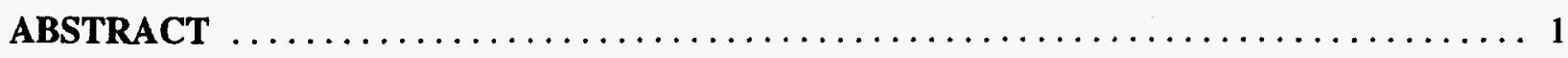

1. INTRODUCTION $\ldots \ldots \ldots \ldots \ldots \ldots \ldots \ldots \ldots \ldots \ldots \ldots \ldots \ldots \ldots \ldots \ldots \ldots$

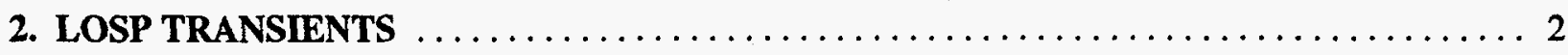

2.1 LOSP-1: LOSS-OF-OFF-SITE POWER (LOSP) CERTIFICATION BASIS CASE . . . . 2

2.1.1 Selection of All LOSP Limiting Cases (LOSP-1, LOSP-2, and LOSP-3) $\ldots \ldots \ldots 2$

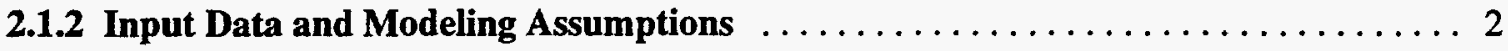

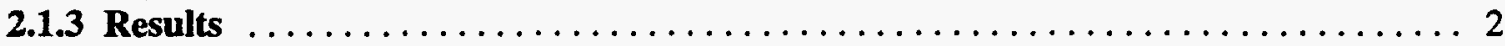

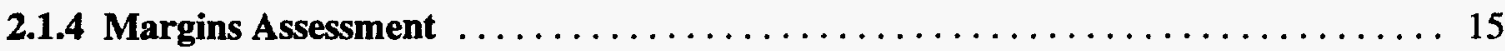

2.2 LOSP-2: BEYOND-DESIGN-BASIS ANALYSIS-ATWS CASE $\ldots \ldots \ldots \ldots \ldots \ldots$

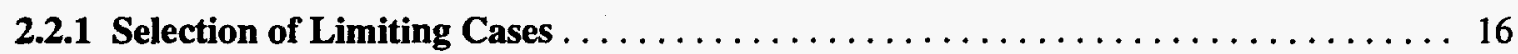

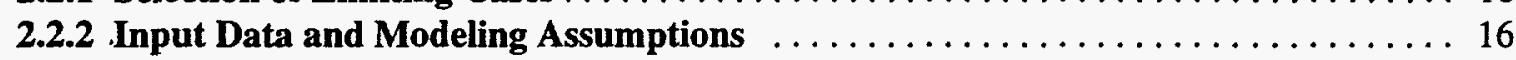

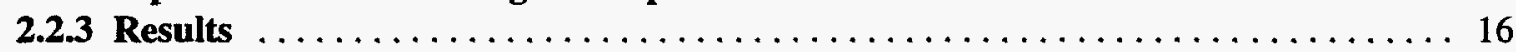

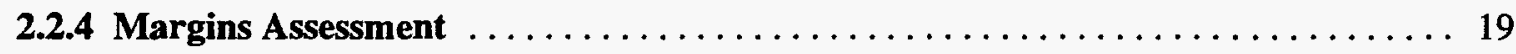

2.3 LOSP-3: WORST CASE FOR TRANSITION TO NATURAL CIRCULATION . . . . . 19

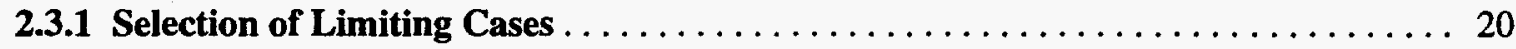

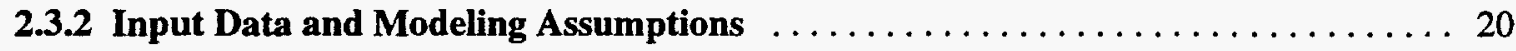

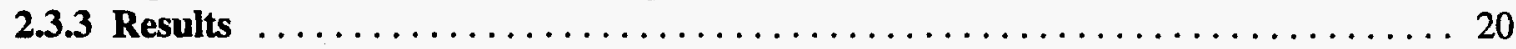

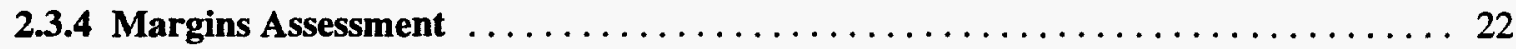

3. RAPID DEPRESSURIZATION ACCIDENTS $\ldots \ldots \ldots \ldots \ldots \ldots \ldots \ldots \ldots \ldots \ldots \ldots$

3.1 SELECTION OF LIMITING CASES FOR PRESSURE BOUNDARY FAULT $\ldots \ldots .32$

3.2 INPUT DATA AND MODELING ASSUMPTIONS $\ldots \ldots \ldots \ldots \ldots \ldots \ldots \ldots \ldots$

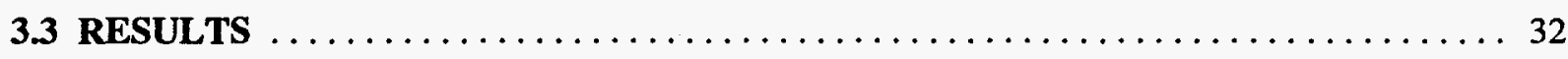

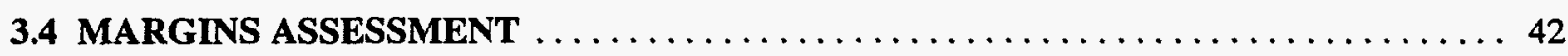

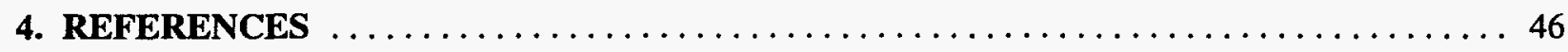





\section{LIST OF FIGURES}

Figure

Page

1. Nodalization diagram of the ANSR three-element RELAP5 core model $\ldots \ldots \ldots \ldots \ldots \ldots \ldots$

2. Total core flow transient during LOSP-1 [LOSP with no pre-scram control rod motion, normal (slow) letdown valve closure, and no secondary reactor shutdown system

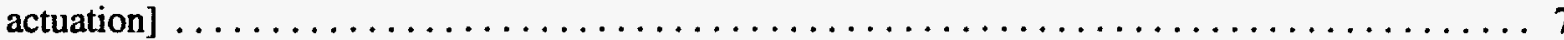

3. Temperature transient at the lower fuel element $99.9 \%$ hot channel exit in reference to the core inlet temperature during LOSP-1 [LOSP with no pre-scram control rod motion, normal (slow) letdown valve closure, and no secondary reactor shutdown system actuation] .........

4. Reactor power (sum of prompt fission and decay heat) and reactivity response during LOSP-1 [LOSP with no pre-scram control rod motion, normal (slow) letdown valve closure, and no secondary reactor shutdown system actuation $] \ldots \ldots \ldots \ldots \ldots \ldots \ldots \ldots \ldots \ldots$

5. Pressure response at the lower fuel element $99.9 \%$ hot channel exit during LOSP-1 [LOSP with no pre-scram control rod motion, normal (slow) letdown valve closure, and no secondary reactor shutdown system actuation]

6. Total letdown, makeup, and total accumulator flow response during LOSP-1 [LOSP with no prescram control rod motion, normal (slow) letdown valve closure, and no secondary reactor

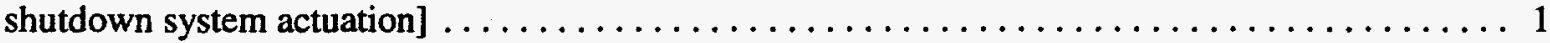

7. Liquid level within each accumulator during LOSP-1 [LOSP with no pre-scram control rod motion, normal (slow) letdown valve closure, and no secondary reactor shutdown system

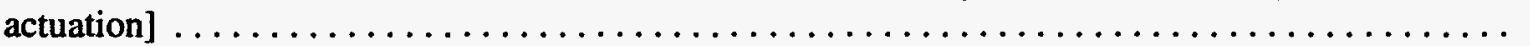

8. Comparison of $\mathrm{FE}$ and $\mathrm{CHF}$ thermal limit ratio minima at the lower fuel element $(99.9 \%$ nonexceedance probability) hot channel exit during LOSP-1 [LOSP with no pre-scram control rod motion, normal (slow) letdown valve closure, and no secondary reactor shutdown system

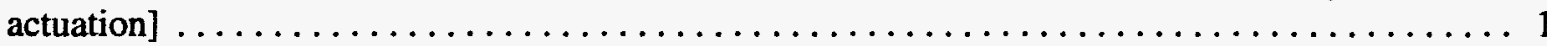

9. Parameters pertinent to the Costa limiting heat flux calculations during LOSP-1 [LOSP with no pre-scram control rod motion, normal (slow) letdown valve closure, and no secondary reactor

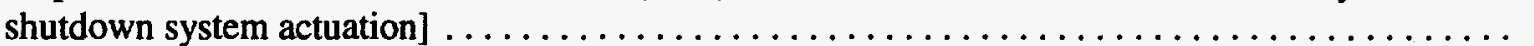

10. Comparison of FE thermal limit ratio at the lower fuel element $(99.9 \%$ nonexceedance probability) hot channel exit between LOSP-1 and LOSP-2 [LOSP-1 is a LOSP with no prescram control rod motion, normal (slow) letdown valve closure, and no secondary reactor shutdown system actuation; LOSP-2 is same as LOSP-1 except primary scram system fails and the secondary scram actuates as designed]

11. Total core flow transient during LOSP-3 (extended LOSP with diesel generator failure and gradually opened letdown valves to accomplish total primary system depressurization before the pony

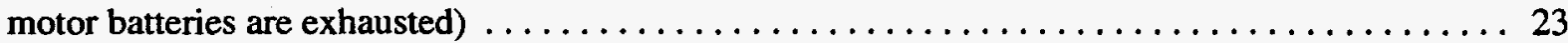

12. Closeup of total core flow transient after pony motor coastdown during LOSP-3 (extended LOSP with diesel generator failure and gradually opened letdown valves to accomplish total primary system depressurization before the pony motor batteries are exhausted) $\ldots \ldots \ldots \ldots \ldots \ldots \ldots \ldots 24$

13. Temperature response at the lower fuel element $95 \%$ hot channel exit in reference to the core inlet temperature during LOSP-3 (extended LOSP with diesel generator failure and gradually opened letdown valves to accomplish total primary system depressurization before the pony motor

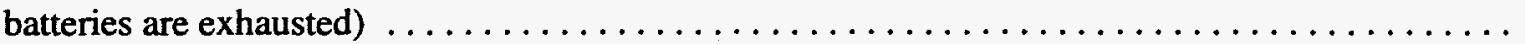




\section{LIST OF FIGURES (continued)}

Figure

Page

14. Pressure at the lower fuel element $95 \%$ hot channel exit during LOSP-3 (extended LOSP with diesel generator failure and gradually opened letdown valves to accomplish total primary system depressurization before the pony motor batteries are exhausted) $\ldots \ldots \ldots \ldots \ldots \ldots \ldots$

15. Total letdown, makeup, and total accumulator flow during LOSP-3 (extended LOSP with diesel generator failure and gradually opened letdown valves to accomplish total primary system depressurization before the pony motor batteries are exhausted) $\ldots \ldots \ldots \ldots \ldots \ldots \ldots \ldots$

16. Liquid level within each accumulator during LOSP-3 (extended LOSP with diesel generator failure and gradually opened letdown valves to accomplish total primary system depressurization

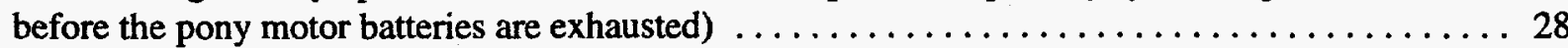

17. Comparison of FE and CHF thermal limit ratio minima at the lower fuel element (95\% nonexceedance probability) hot channel exit during LOSP-3 (extended LOSP with diesel generator failure and gradually opened letdown valves to accomplish total primary system depressurization before the pony motor batteries are exhausted $) \ldots \ldots \ldots \ldots \ldots \ldots \ldots \ldots$

18. Parameters pertinent to the Costa limiting heat flux calculations during LOSP-3 (extended LOSP with diesel generator failure and gradually opened letdown valves to accomplish total primary system depressurization before the pony motor batteries are exhausted)

19. Closeup for parameters pertinent to the Costa limiting heat flux calculations during LOSP-3 (extended LOSP with diesel generator failure and gradually opened letdown valves to accomplish total primary system depressurization before the pony motor batteries are exhausted $) \ldots \ldots \ldots \ldots .31$

20. Core exit pressure during a 76-mm (3-in.)-diam instantaneous core inlet pipe break with coincident LOSP for the three-element-core configuration $\ldots \ldots \ldots \ldots \ldots \ldots \ldots \ldots \ldots \ldots$

21. Reactor power decay during a 76-mm (3-in.)-diam instantaneous core inlet region pipe break with coincident LOSP for the three-element-core configuration $\ldots \ldots \ldots \ldots \ldots \ldots \ldots \ldots \ldots$

22. Important mass flow rates during a 76-mm (3-in.)-diam instantaneous core inlet region pipe break with coincident LOSP for the three-element-core configuration $\ldots \ldots \ldots \ldots \ldots \ldots \ldots . \ldots 38$

23. Thermal limit ratios during a 76-mm (3-in.)-diam instantaneous core inlet region pipe break with coincident LOSP for the three-element-core configuration $\ldots \ldots \ldots \ldots \ldots \ldots \ldots \ldots \ldots$

24. FE thermal limit ratios for limiting break sizes for core inlet breaks with coincident LOSP

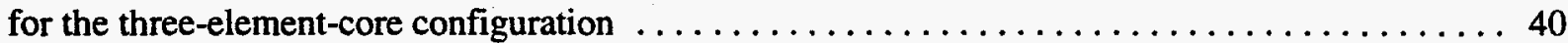

25. CHF thermal limit ratios for limiting break sizes for core inlet breaks with coincident LOSP

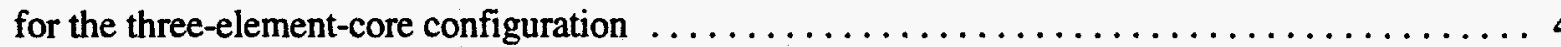

26. FE thermal limit ratios for limiting break sizes for hot-leg breaks with coincident LOSP for the

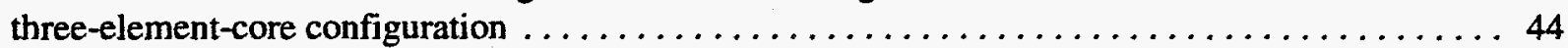

27. CHF thermal limit ratios for limiting break sizes for hot-leg breaks with coincident LOSP for the three-

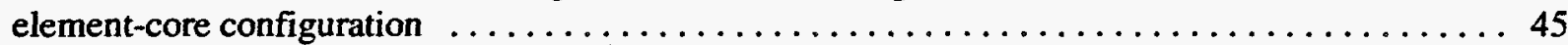




\section{LIST OF TABLES}

Table

$\underline{\text { Page }}$

1. Relative power densities in each node of the RELAP5 ANSR three-element-core model $\ldots \ldots \ldots 4$

2. Uncertainty factors in each node of the RELAP5 ANSR three-element-core model $\ldots \ldots \ldots \ldots .5$

3. Sequence of events for the certification basis case (LOSP-1) $\ldots \ldots \ldots \ldots \ldots \ldots \ldots \ldots \ldots$

4. Sequence of events for the LOSP-2: total failure of primary reactor scram system $\ldots \ldots \ldots \ldots 17$

5. Effects of scram delay time and nonexceedance probability on timing and magnitude of the first

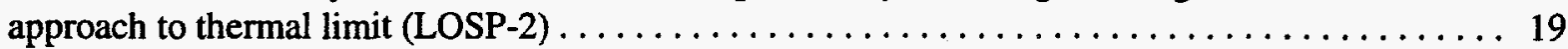

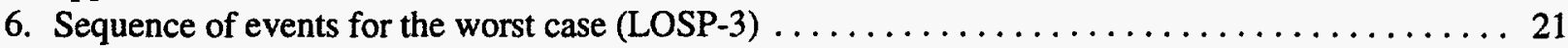

7. Sequence of events for 76-mm (3.0-in.-)-diam instantaneous pipe break near core inlet . . . . . 43 



\section{LIST OF ACRONYMS}

$\begin{array}{ll}\text { ANSR } & \begin{array}{l}\text { Advanced Neutron Source reactor } \\ \text { beginning-of-cycle } \\ \text { critical heat flux } \\ \text { core pressure boundary tube } \\ \text { CHF }\end{array} \\ \text { central processing unit } \\ \text { CPU } & \begin{array}{l}\text { conceptual safety analysis report } \\ \text { flow excursion }\end{array} \\ \text { CSAR } & \text { High Flux Isotope Reactor } \\ \text { FE } & \text { hot spot } \\ \text { HFIR } & \text { ibncipient boiling } \\ \text { HS } & \begin{array}{l}\text { loss-of-offsite power } \\ \text { IB }\end{array} \\ \text { LOSP } & \text { onexceedance probability level } \\ \text { NEPL } & \text { rapid depressurization accident }\end{array}$




\title{
ADVANCED NEUTRON SOURCE REACTOR CONCEPTUAL SAFETY ANALYSIS REPORT, THREE-ELEMENT-CORE DESIGN: CHAPTER 15, ACCIDENT ANALYSIS
}

\author{
N. C. J. Chen \\ M. W. Wendel \\ G. L. Yoder \\ R. M. Harrington
}

\begin{abstract}
In order to utilize reduced enrichment fuel, the three-element-core design for the Advanced Neutron Source has been proposed. The proposed core configuration consists of inner, middle, and outer elements, with the middle element offset axially beneath the inner and outer elements, which are axially aligned. The three-element-core RELAP5 model assumes that the reactor hardware is changed only within the core region, so that the loop piping, heat exchangers, and pumps remain as assumed for the two-element-core configuration. To assess the impact of changes in the core region configuration and the thermal-hydraulic steady-state conditions, the safety analysis has been updated. This report gives the safety margins for the loss-of-off-site power and pressure-boundary fault accidents based on the RELAP5 results. All margins are greater for the three-element-core simulations than those calculated for the two-element core.
\end{abstract}

\section{INTRODUCTION}

This report documents the three-element-core thermal-hydraulic Conceptual Safety Analysis, following the same format as that of the two-element-core CSAR update. ${ }^{1}$ Results for both loss-of-off-site power (LOSP) and rapid depressurization accident (RDA) events are provided. The description of these transients includes: (1) selection of limiting cases, (2) input data and modeling assumptions, (3) results, and (4) margin assessment. The twoelement-core RELAP5 input model is described in ref. 2. This two-element model was modified in the core region only to produce a RELAP5 input model for the three-element core-configuration. ${ }^{3}$ The sections, along with tables and figures, were numbered so that the three-element-core CSAR can be attached to the end of the original two-element core-safety analysis as a comprehensive integrated report. 


\section{LOSP TRANSIENTS}

\subsection{LOSP-1: LOSS OF OFF-SITE POWER (LOSP) CERTIFICATION BASIS CASE}

This section reports the RELAP5 results for the certification basis LOSP (LOSP-1) with the three-element-core configuration, wherein the primary loop pumps, the pressurizing pump, and the secondary loop pumps all coast down immediately upon LOSP, and certain coincident events are assumed to occur, as explained in Sect. 15.2.5.1. Recovery of ac power, although likely to happen within 1 to $2 \mathrm{~min}$ of the LOSP, is not assumed: indeed, as demonstrated in Sect. 15.2.11, ac power is not needed for the removal of decay heat after a LOSP. The objective of the certification basis case analysis is to verify that the acceptance criteria for Anticipated Events are met with margin without taking credit for the secondary scram system. The criteria of primary interest for this analysis are the critical heat flux (CHF) and the flow excursion (FE) limitations.

\subsubsection{Selection of All LOSP Limiting Cases (LOSP-1, LOSP-2, and LOSP-3)}

See Sect. 15.2.5.1 in ref. 1 for the rationale behind the selection of LOSP-1 for the three-element-core configuration.

\subsubsection{Input Data and Modeling Assumptions}

RELAP5/MOD3.1.1.1 (which includes the ANS updates described in Sect. 15.0.4 of the 1992 CSAR issue) was used to perform the three-element-core LOSP simulations. A fine discretization comparable to that used in the updated two-element-core analysis was defined.

The three-element-core model was constructed by modifying the two-element core model in the core region only, in order to create three parallel-core flow paths instead of two, as well as three sets of fuel heat structures instead of two. The hot- and cold-leg piping, pumps, heat exchangers, and accumulators are identical to that assumed in the two-element-core model. The geometry, operating conditions, and heat loading of the three-element core were presented in the January and March 1995 ANS Progress Report. ${ }^{4.5}$ The outer and inner elements are on the same axial level, but the middle element is lower. The nodalization diagram for the three-element core is shown in Fig. 1. The name of the input file for the three-element-core model is LOSP1in.3el.

The relative power densities and uncertainty factors assumed for the three-element-core fuel heat structures are shown Tables 1 and 2.

\subsubsection{Results}

The sequence of events for the certification basis case (LOSP-1) is described in Table 3.

At time zero, ac power is lost, so the ac motors on the primary coolant pumps, the secondary coolant pumps, and the pressurizing pumps all immediately begin to coast down. Figures 2 through 9 show pertinent system parameters over the $100 \mathrm{~s}$ following the LOSP. The total core flow (see Fig. 2) at first declines rapidly from the nominal value (about $2350 \mathrm{~kg} / \mathrm{s}$ ) and then approaches pony motor flow (at $10 \%$ of the nominal) gradually over approximately $100 \mathrm{~s}$, as characterized by the pump coastdown. The declining core flow causes an initial increase in coolant bulk temperature at the lower fuel element exit, as indicated in Fig. 3, but it decreases sharply upon reactor scram. Likewise, the fuel surface temperature at the hot spot increases initially and then turns around rapidly after reactor scram. The core inlet temperature remains unchanged. 

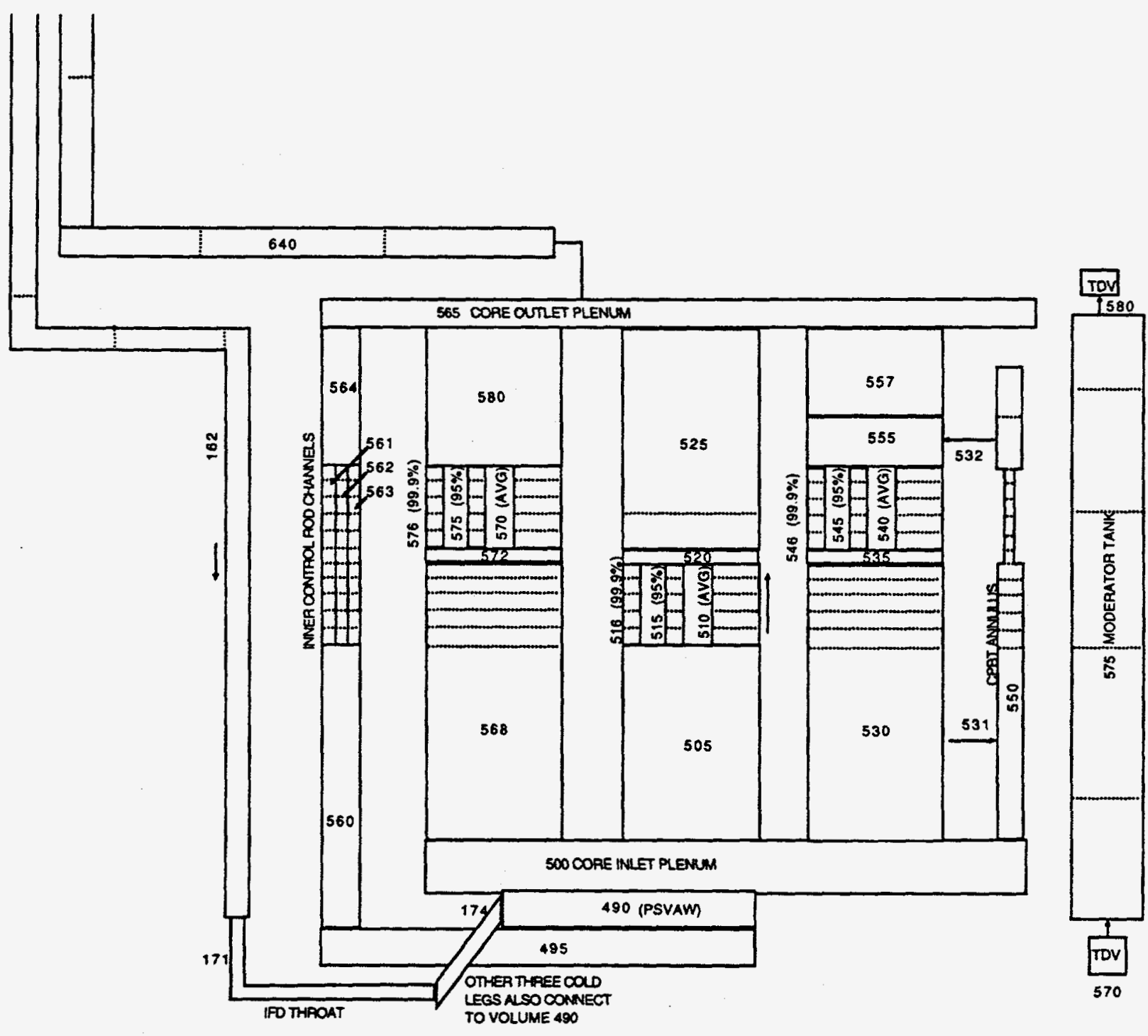

Fig. 1. Nodalization diagram of the ANSR three-element RELAP5 model. 
Table 1. Relative power densities in each node of the RELAP5 ANSR three-element-core model

\begin{tabular}{|c|c|c|c|c|}
\hline Node & Avg channel & Hot channel & CHF hot stripe & FE hot stripe \\
\hline \multicolumn{5}{|c|}{ Outer element one day into the cycle } \\
\hline 1 (Inlet) & 1.351 & 1.622 & 1.710 & 1.664 \\
\hline 2 & 1.285 & 1.618 & 1.658 & 1.554 \\
\hline 3 & 1.165 & 1.495 & 1.546 & 1.415 \\
\hline 4 & 1.026 & 1.348 & 1.405 & 1.266 \\
\hline 5 (Outlet) & 0.882 & 1.155 & 1.258 & 0.906 \\
\hline \multicolumn{5}{|c|}{ Middle element at beginning of cycle } \\
\hline 1 (Inlet) & 1.217 & 1.654 & 1.759 & 1.648 \\
\hline 2 & 1.257 & 1.624 & 1.647 & 1.573 \\
\hline 3 & 1.260 & 1.523 & 1.566 & 1.459 \\
\hline 4 & 1.244 & 1.408 & 1.452 & 1.335 \\
\hline 5 (Outlet) & 1.158 & 1.230 & 1.326 & 1.025 \\
\hline \multicolumn{5}{|c|}{ Inner element at end of cycle } \\
\hline 1 (Inlet) & 0.862 & 1.518 & 1.569 & 1.379 \\
\hline 2 & 0.732 & 1.254 & 1.351 & 1.156 \\
\hline 3 & 0.668 & 1.115 & 1.150 & 1.029 \\
\hline 4 & 0.563 & 0.956 & 1.018 & 0.868 \\
\hline 5 (Outlet) & 0.385 & 0.790 & 0.858 & 0.693 \\
\hline
\end{tabular}


Table 2. Uncertainty factors in each node of the RELAP5 ANSR three-element-core model

\begin{tabular}{lccc}
\hline Node & Hot channel & $\begin{array}{l}\text { CHF hot } \\
\text { stripe }\end{array}$ & $\begin{array}{l}\text { FE hot } \\
\text { stripe }\end{array}$ \\
\hline \multicolumn{4}{c}{ 95\% Nonexceedance probability } \\
1 (Inlet) & 1.074 & 1.631 & 1.305 \\
2 & 1.074 & 1.554 & 1.305 \\
3 & 1.074 & 1.554 & 1.305 \\
4 & 1.074 & 1.554 & 1.305 \\
5 (Outlet) & 1.074 & 1.631 & 1.305 \\
& $99.9 \%$ Nonexceedance probability \\
1 (Inlet) & 1.113 & 1.995 & 1.592 \\
2 & 1.113 & 1.899 & 1.592 \\
3 & 1.113 & 1.899 & 1.592 \\
4 & 1.113 & 1.899 & 1.592 \\
5 (Outlet) & 1.113 & 1.995 & 1.592 \\
\hline
\end{tabular}


Table 3. Sequence of events for the certification basis case (LOSP-1)

\begin{tabular}{|c|c|}
\hline $\begin{array}{l}\text { Time } \\
\text { (s) }\end{array}$ & Event \\
\hline 0.00 & $\begin{array}{l}\text { Loss of off-site (ac) power; diesel electric generators fail to start. Primary coolant pumps, } \\
\text { pressurizer pump, and secondary coolant pumps begin coasting down }\end{array}$ \\
\hline 0.61 & $\begin{array}{l}\text { Flux/flow ratio reaches } 1.2 \text { (the nominal scram set point of } 1.15 \text { plus } 5 \% \text { for uncertainties and } \\
\text { set point drift) }\end{array}$ \\
\hline 0.63 & Pressurizing (i.e., makeup) system flow ceases upon check valve closure \\
\hline 0.81 & Scram signal initiated after $200-\mathrm{ms}$ delay that accounts for flow sensor response \\
\hline 0.84 & Inner control rods begin scram insertion stroke (30-ms unlatch delay completed) \\
\hline 0.86 & Costa FE limit ratio reaches a minimum of 3.3 (at $99.9 \%$ nonexceedance probability level) \\
\hline 0.91 & Accumulator injection begins \\
\hline 8. & Total letdown flow stops as letdown valves reach the fully closed position \\
\hline 10. & Secondary flow in main heat exchangers reaches natural circulation at $3.23 \%$ of the nominal \\
\hline 98.63 & $\begin{array}{l}\text { Pressure at sensor location decreases below the reactor scram set point of } 1.40 \mathrm{MPa}(20 \% \\
\text { below the nominal) }\end{array}$ \\
\hline 100. & $\begin{array}{l}\text { Primary coolant pumps equilibrate at pony motor speed }(\sim 10 \% \text { of main motor speed }) \text { and } \\
\text { calculation stopped }\end{array}$ \\
\hline
\end{tabular}




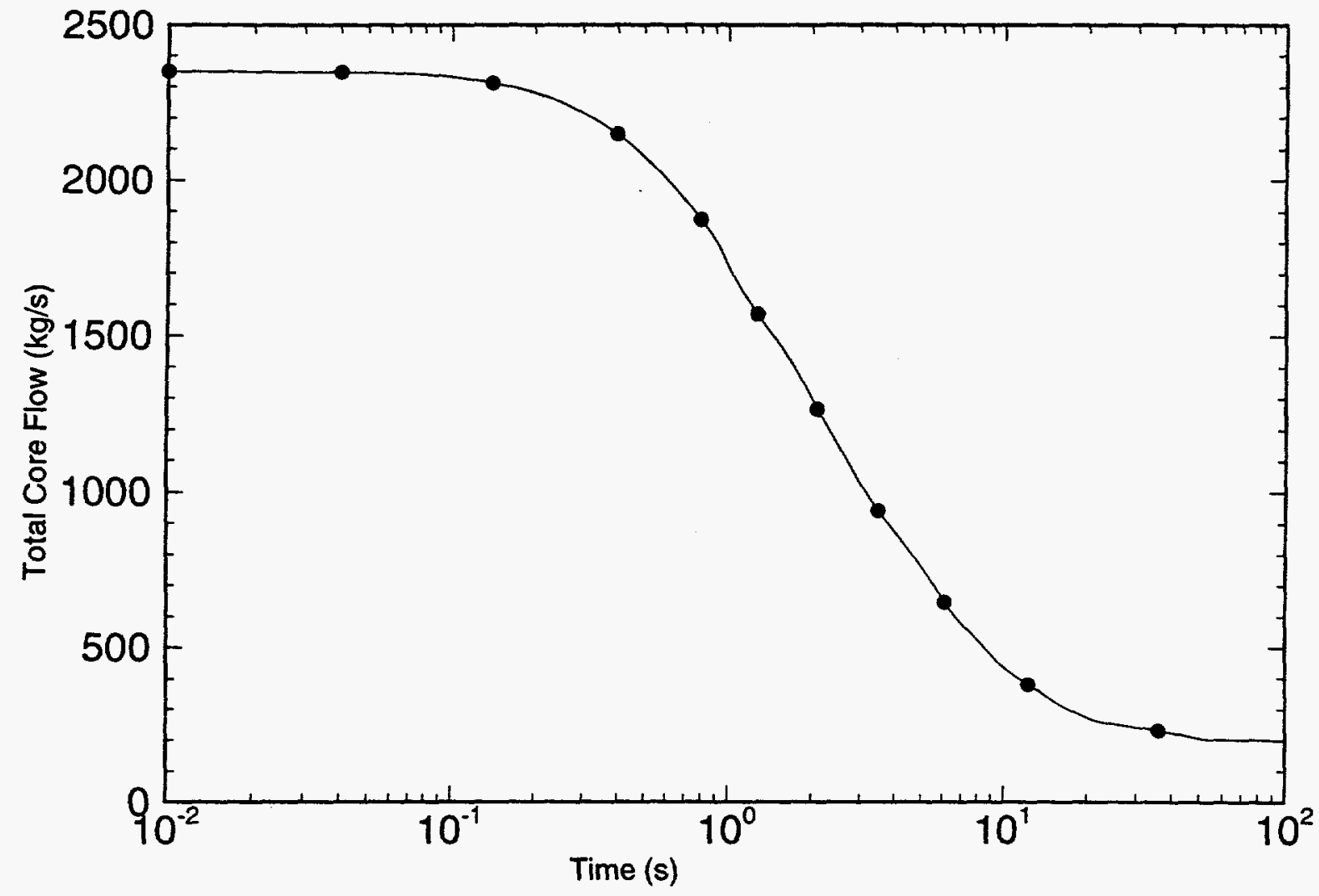

Fig. 2. Total core flow transient during LOSP-1 [LOSP with no pre-scram control rod motion, normal (slow) letdown valve closure, and no secondary reactor shutdown system actuation]. 


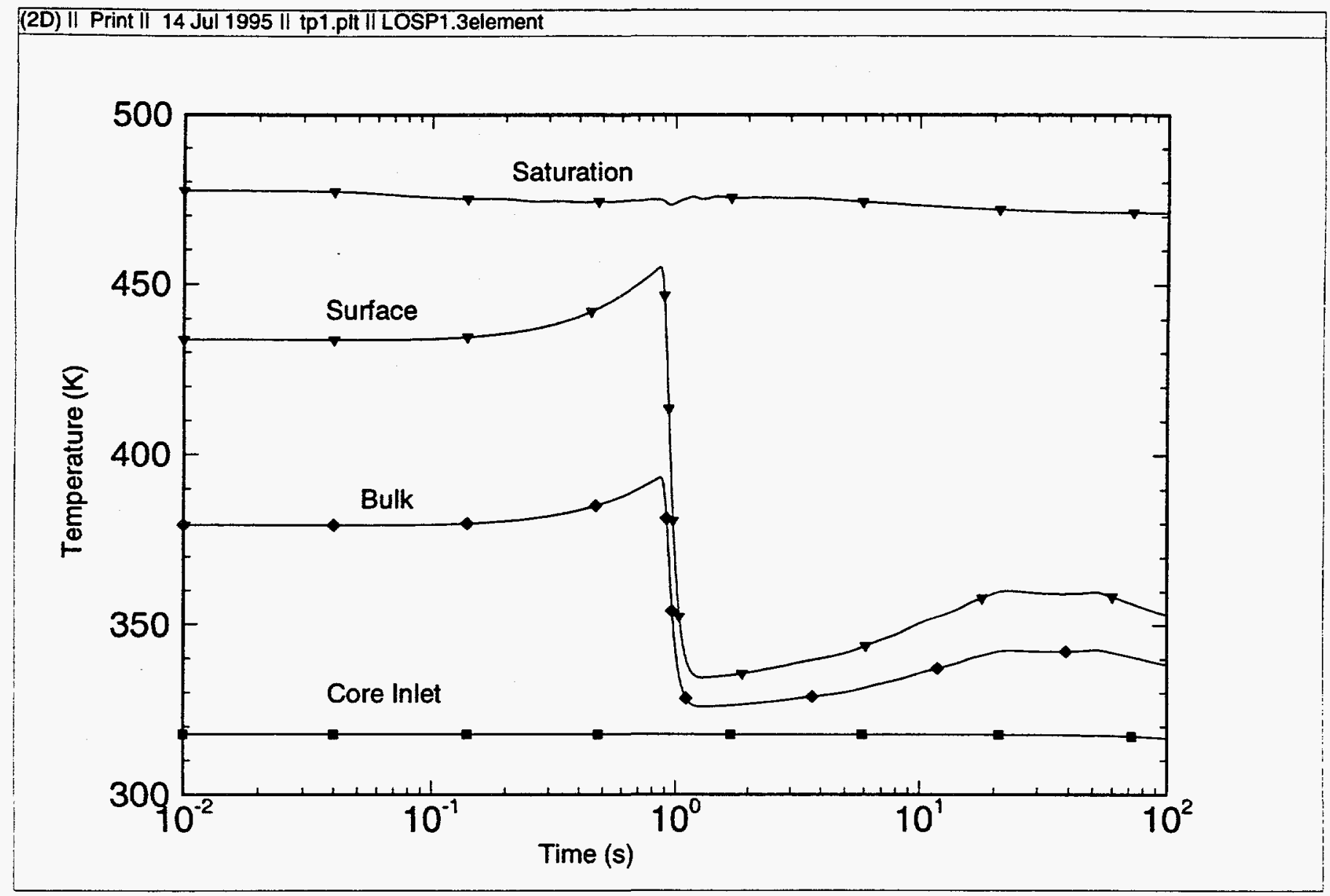

Fig. 3. Temperature transient at the lower fuel element $99.9 \%$ hot channel exit in reference to the core inlet temperature during LOSP-1 [LOSP with no pre-scram control rod motion, normal (slow) letdown valve closure, and no secondary reactor shutdown system actuation]. 


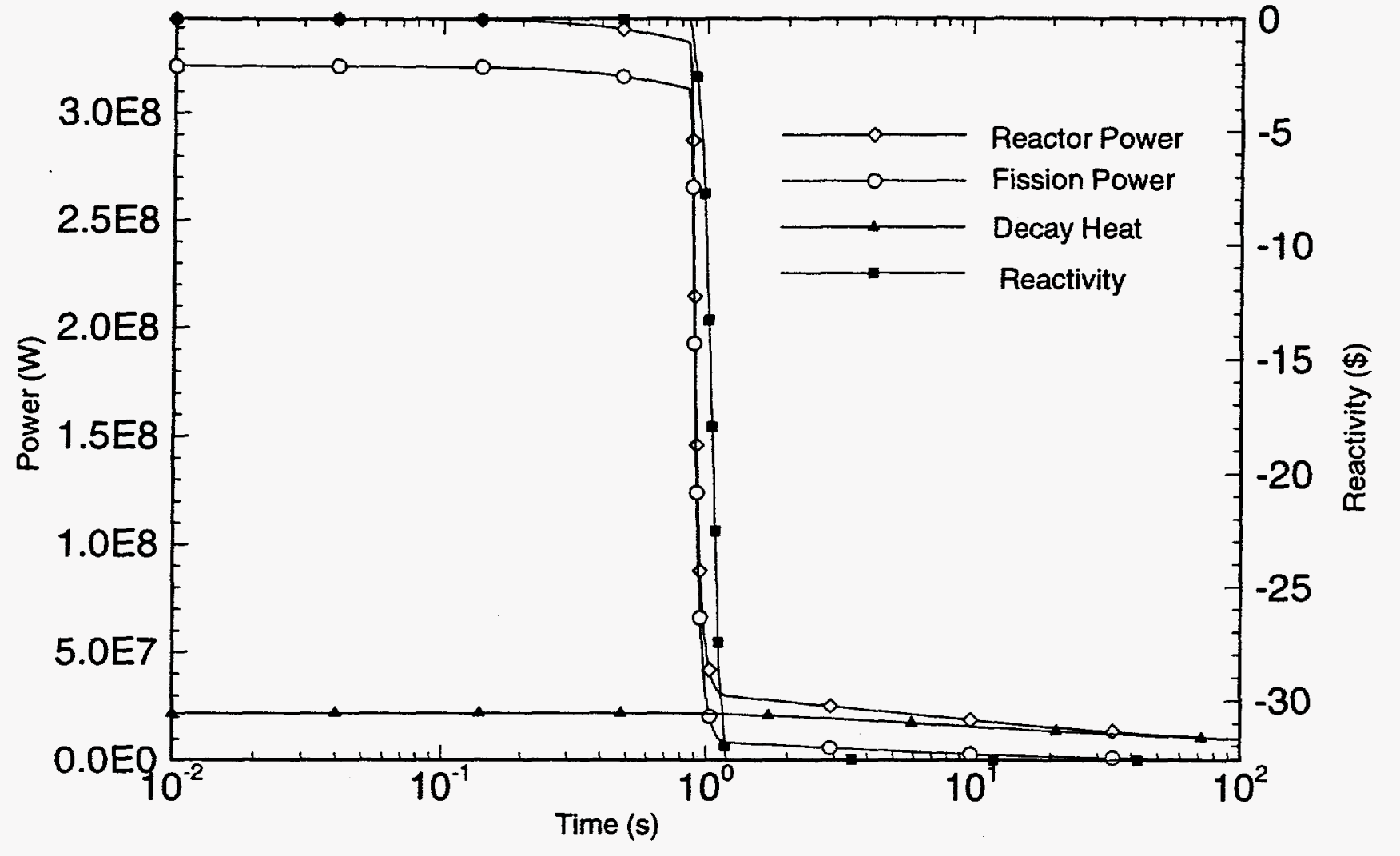

Fig. 4. Reactor power (sum of prompt fission and decay heat) and reactivity response during LOSP-1 [LOSP with no pre-scram control rod motion, normal (slow) letdown valve closure, and no secondary reactor shutdown system actuation]. 


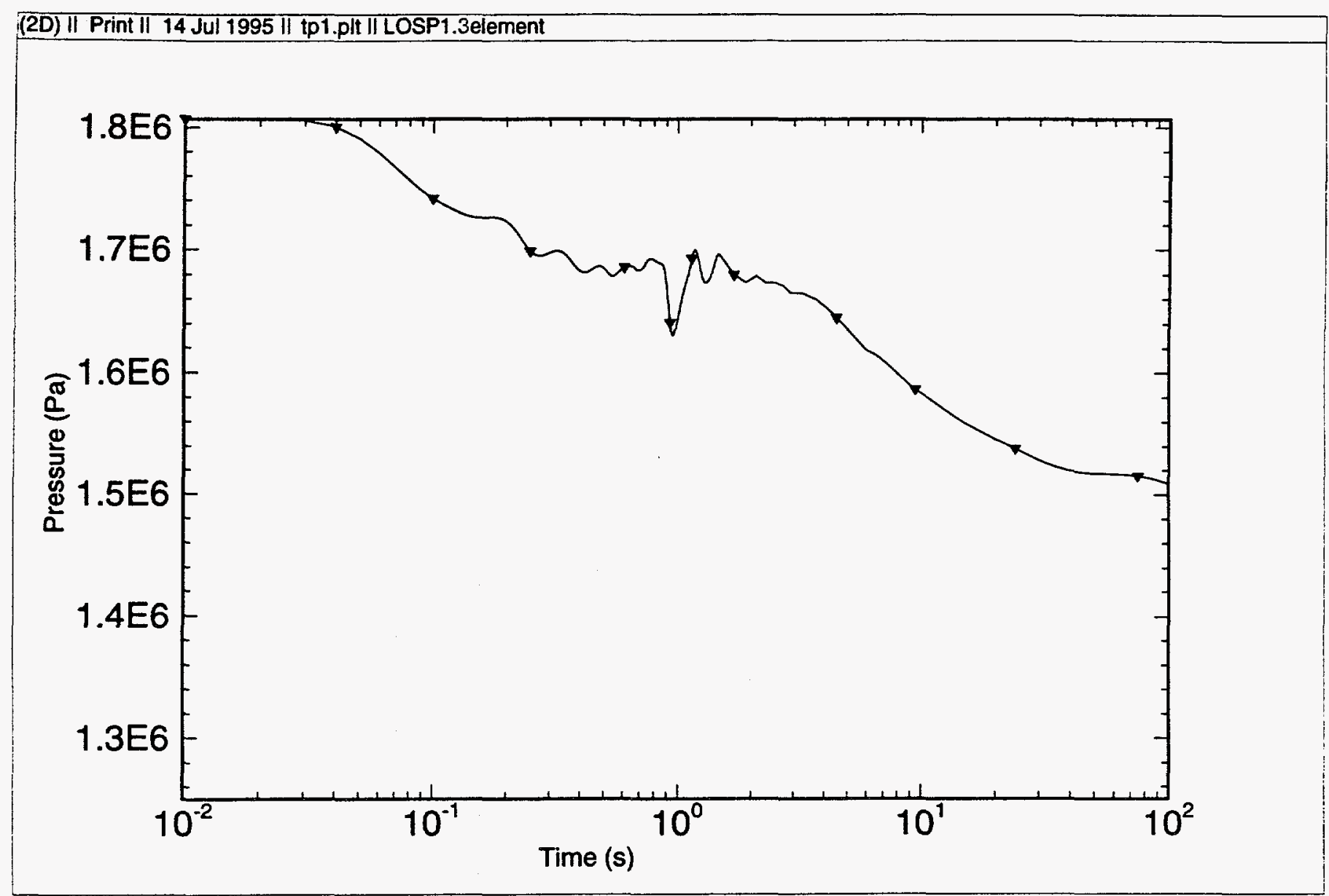

Fig. 5. Pressure response at the lower fuel element $99.9 \%$ hot channel exit during LOSP-1 [LOSP with no pre-scram control rod motion, normal (slow) letdown valve closure, and no secondary reactor shutdown system actuation]. 


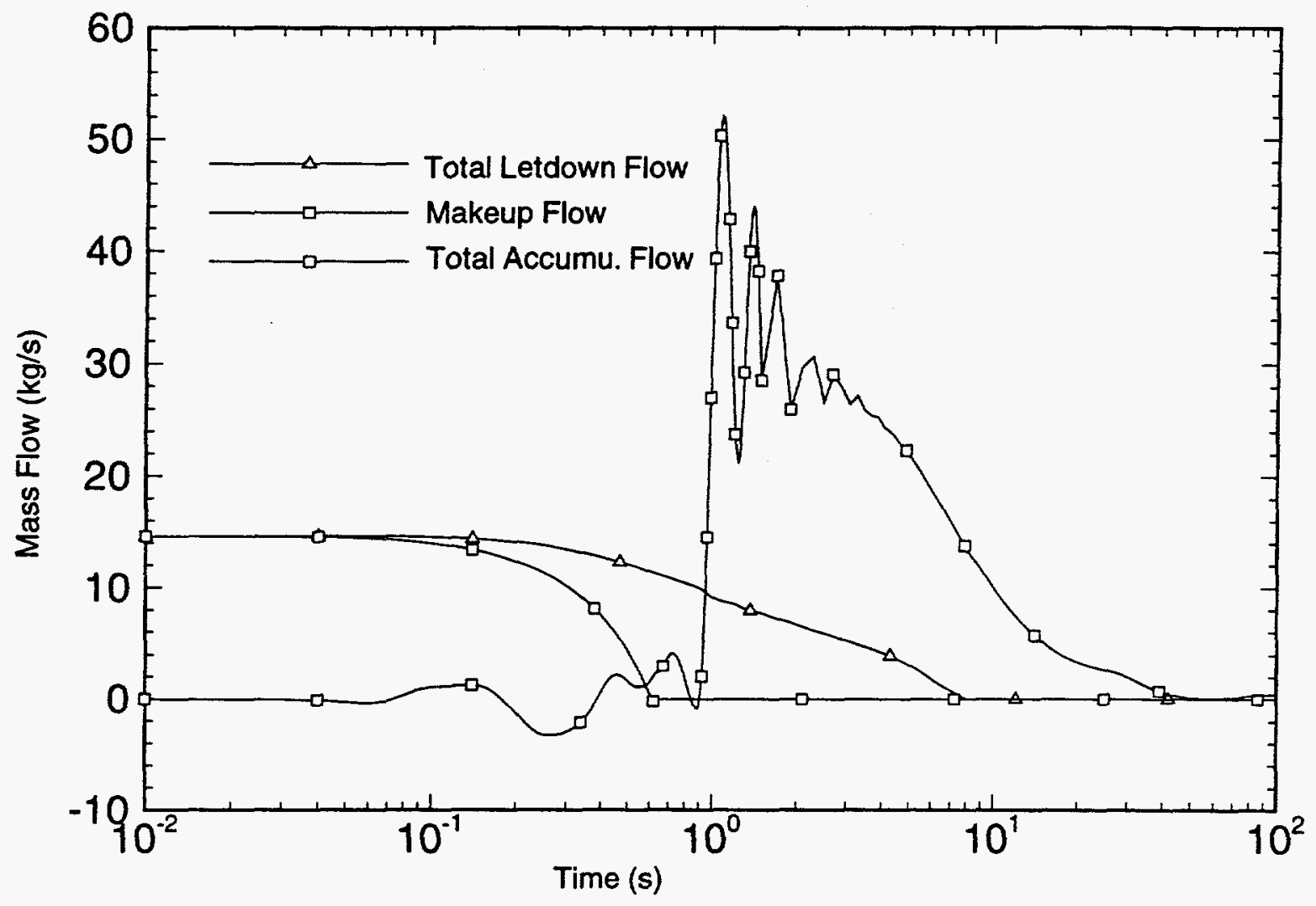

Fig. 6. Total letdown, makeup, and total accumulator flow response during LOSP-1 [LOSP with no pre-scram control rod motion, normal (slow) letdown valve closure, and no secondary reactor shutdown system actuation]. 


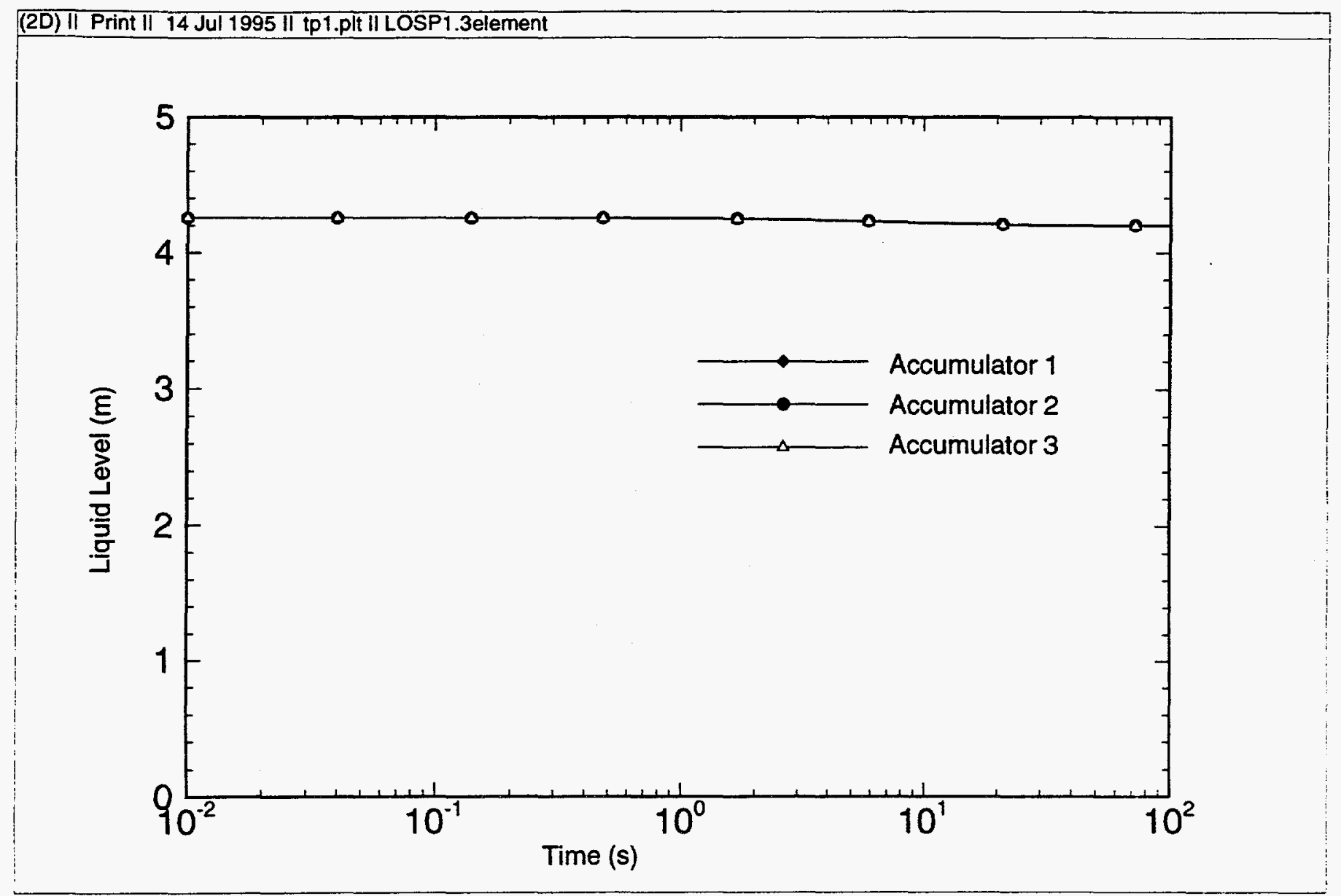

Fig. 7. Liquid level within each accumulator during LOSP-1 [LOSP with no pre-scram control rod motion, normal (slow) letdown valve closure, and no secondary reactor shutdown system actuation]. 


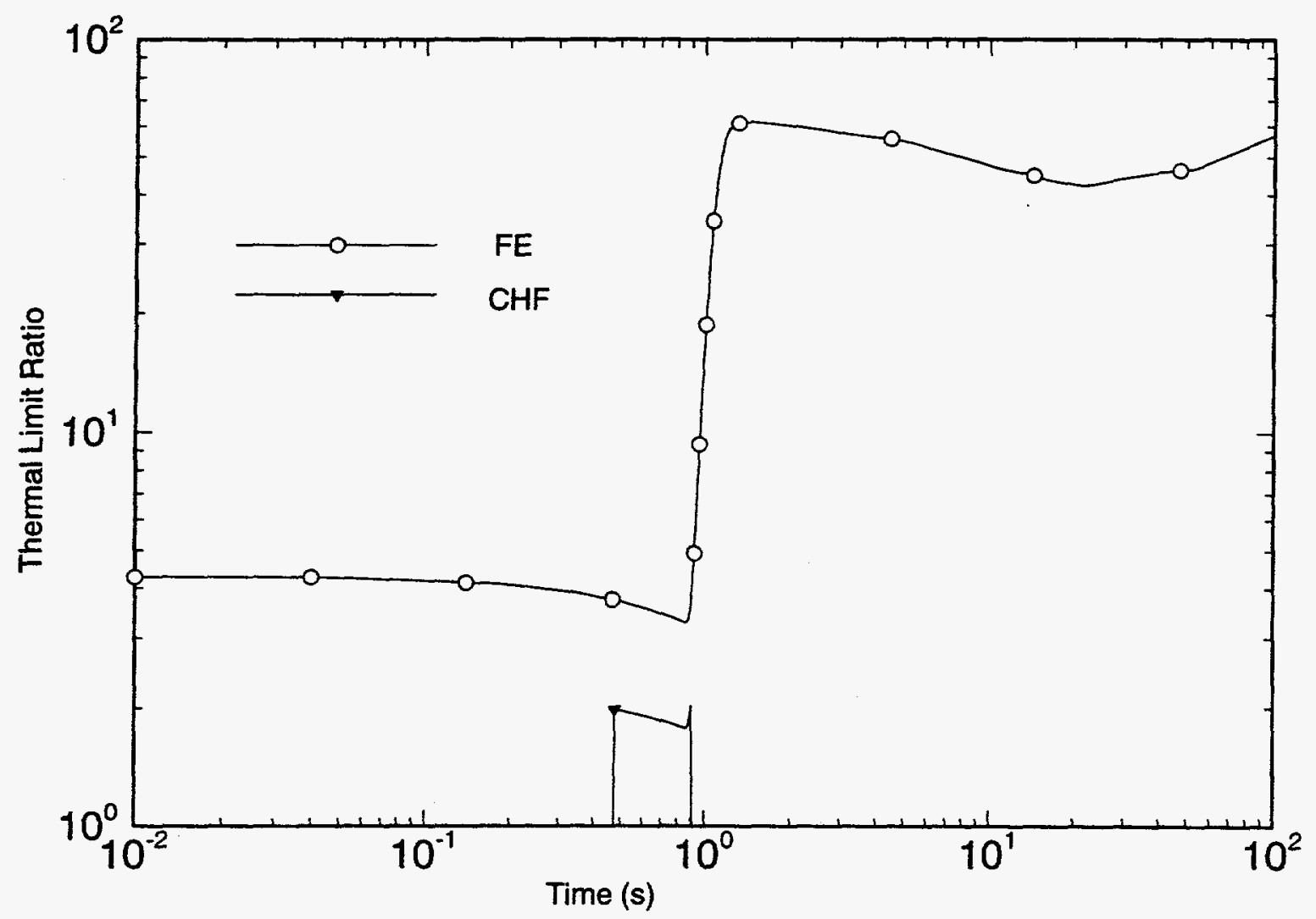

Fig. 8. Comparison of FE and CHF thermal limit ratio minima at the lower fuel element (99.9\% nonexceedance probability) hot channel exit during LOSP-1 [LOSP with no pre-scram control rod motion, normal (slow) letdown valve closure, and no secondary reactor shutdown system actuation]. 


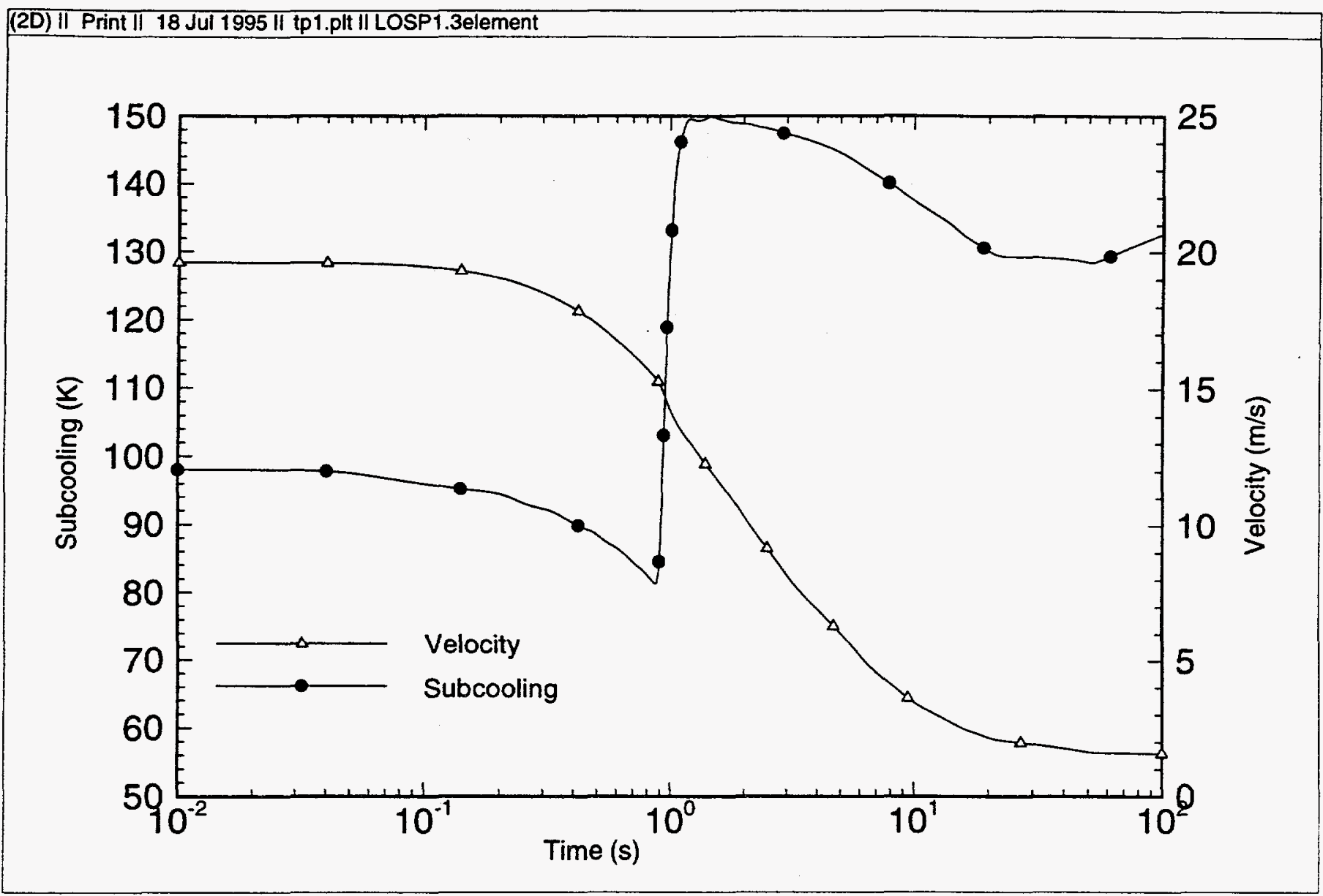

Fig. 9. Parameters pertinent to the Costa limiting heat flux calculations during LOSP-1 [LOSP with no pre-scram control rod motion, normal (slow) letdown valve closure, and no secondary reactor shutdown system actuation]. 
Reactor power (sum of prompt fission power and decay heat) and reactivity are presented in Fig. 4. Reactivity feedback from higher coolant temperatures and lower coolant densities causes the core power to drift downward prior to scram. After exceeding the set point for reactor trip on high flux-to-flow ratio (nominal set point of 1.15), the reactor scrams, and the power drops sharply. Thereafter, the power continues to decrease and approach the decay heat level.

Pressure at the lower fuel element exit is displayed in Fig. 5. The pressure falls primarily as a result of the primary coolant pumps coasting down, but also because of the loss of pressurizing system flow and coolant escape from the slowly closing letdown valves; however, the net depressurization rate is slow because of the effect of the accumulators.

Various mass flow rates are shown in Fig. 6. After losing the ac-powered motor, the pressurizing pump coasts down immediately, and so does the makeup flow. The declining pump head against a relatively higher system pressure causes the makeup flow to decrease to zero at about $1 \mathrm{~s}$ as the check valves shut completely when the pressure differential across the pump is reversed. In response to the falling system pressure, the total letdown flow declines as the letdown valves begin to close. The closure is completed at about $8 \mathrm{~s}$, as calculated by RELAP5.

In contrast to makeup and letdown flows, the net accumulator injection does not begin until about $0.9 \mathrm{~s}$ into the transient. After the reactor scram, the accumulator injection reaches its maximum (about $52 \mathrm{~kg} / \mathrm{s}$ ) and exceeds the total letdown flow because the primary coolant contracts as it is rapidly cooled. As mentioned above, this is a very slow depressurization event so that a correspondingly small amount of accumulator injection should be expected (area underneath the total accumulator mass flow rate curve). This fact is made evident by the calculated accumulator liquid level (see Fig. 7), where the heavy-water level remains nearly constant at $\sim 4.3 \mathrm{~m}$ during the transient.

Figure 8 compares minima of the $\mathrm{FE}$ and $\mathrm{CHF}$ ratios (both minima occurred in the lower fuel element $99.9 \%$ nonexceedance probability channel). Both minima are greater than unity, indicating that the thermal limits are not exceeded and no fuel damage exists. The CHF is shown to be the most limiting, with a minimum of 1.8 at the closest approach to the thermal limit. Note that the CHF is not calculated by RELAP5 if the fuel surface temperature is less than the local coolant saturation temperature. Upon LOSP, subcooling decreases to a minimum and recovers greatly after the scram. As a consequence, the FE thermal limit ratio declines from the nominal of about 4.3 to a minimum of 3.3 immediately after the scram. Figure 9 shows the parameters pertinent to the calculation of the Costa FE heat flux limit, which is linearly proportional to local subcooling and square root of local velocity. The coincidence of the subcooling and the Costa limit ratio minima indicates that the greatest contributor toward exceeding the limit at high power, high pressure, and high velocity is the local subcooling. Therefore, the minimum of the Costa limit ratio is determined primarily by the flow coastdown and the timing of the reactor scram.

\subsubsection{Margins Assessment}

The ANSR design is shown to meet the Anticipated Event acceptance criteria for the certification basis case (LOSP-1) because more than a factor of 1.8 margin exists between the hot-spot heat flux and the CHF thermal limits. During the most limiting part of the transient, the velocity is about $15 \mathrm{~m} / \mathrm{s}$ and the subcooling decreases to a minimum of $82 \mathrm{~K}$. The core outlet pressure reaches a corresponding minimum of $1.68 \mathrm{MPa}$. Even though these conditions are above the Costa experimental data range (velocity of 2 to $7 \mathrm{~m} / \mathrm{s}$, pressure of 0.175 to 0.5 $\mathrm{MPa}$, heat flux of 1 to $4 \mathrm{MW} / \mathrm{m}^{2}$ ), the use of the Costa correlation at high velocities appears to provide a conservative prediction of FE when compared with recently acquired data from the thermal-hydraulic test loop. 


\subsection{LOSP-2: BEYOND-DESIGN-BASIS ANALYSIS-ATWS CASE}

This section reports the RELAP5 results for the ATWS case, LOSP-2 for the three-element core configuration. The effects of failure of the primary scram system are explored. Since the secondary scram system is about 0.1 $\mathrm{s}$ slower, a slight delay in scram initiation is experienced. The objective is to verify acceptable thermal margins when the core is under the protection of the secondary scram system only. This situation is an extremely unlikely or a beyond-design-basis accident; therefore, the safety margin was calculated against $95 \%$ nonexceedance probability CHF/FE limits.

\subsubsection{Selection of Limiting Cases}

See Sect. 15.2.5.1 for the rationale behind the selection of LOSP-2.

\subsubsection{Input Data and Modeling Assumptions}

The input data set was named and saved on magnetic tape as LOSP2in.3el. In the model, the primary scram failure and the secondary scram activation was simulated by adding an additional 100-ms delay in the reactor trip.

\subsubsection{Results}

The sequence of events for the LOSP-2 is presented in Table 4.

The overall thermal-hydraulic responses are similar to the certification basis case; hence, only the FE thermal limit ratios are shown in Fig. 10. To quantify the effects of scram timing and different nonexceedance probability levels on safety margins, results from four sensitivity studies (Table 5) are compared with the certification basis case (LOSP-1), represented by the thick curve. For the nominal LOSP-2 (i.e., at $95 \%$ nonexceedance probability), the time and magnitude of the closest approach to the thermal limit are $0.96 \mathrm{~s}$ and 4.0 , respectively. The timing is delayed by $0.1 \mathrm{~s}$ beyond that of LOSP-1, as expected, but the magnitude is higher because the ratio is calculated at the $95 \%$ nonexceedance probability level. When calculated against a $99.9 \%$ nonexceedance probability, the time of the closest approach remains the same, whereas the smallest ratio reached, 3.2, is lower than the 3.3 minimum reached in LOSP-1. The dashed curves, calculated by assuming a scram failure, establish the maximum allowable scram delay without exceeding the $95 \%$ and $99.9 \%$ nonexceedance probabilities, respectively. In these cases, the magnitude at the closest approach to the thermal limit is unity, and their corresponding times are $3.58 \mathrm{~s}$ and $3.12 \mathrm{~s}$. 
Table 4. Sequence of events for the LOSP-2: total failure of primary reactor scram system

Time (s)

Event

0.00

Loss of off-site (ac) power. Primary coolant pumps, pressurizer pump, and secondary coolant pumps begin coasting down

0.61 Flux/flow ratio reaches 1.2 (the nominal scram set point of 1.15 plus $5 \%$ for uncertainties and set point drift)

0.63

Pressurizing (i.e., makeup) system flow ceases upon check valve closure

0.81

Scram signal initiated after 200 ms delay that accounts for flow sensor response

0.84

Inner control rod fails to insert because of postulated failure of primary scram system

0.92 Accumulator injection begins

0.94

Outer control rods begin scram insertion stroke

0.96

Costa FE limit ratio reaches a minimum of 4.0 (at $95 \%$ nonexceedance probability level)

8.0

Total letdown flow stops as letdown valves reach the fully closed position

10.0

Secondary flow in main heat exchangers reaches natural circulation at $3.23 \%$ of the nominal

98.63

Pressure at sensor location decreases below reactor scram set point of $1.40 \mathrm{MPa}(20 \%$ below the nominal)

$100.0 \quad$ Primary coolant pumps equilibrate at pony motor speed ( $10 \%$ of main motor speed) and calculation stopped 


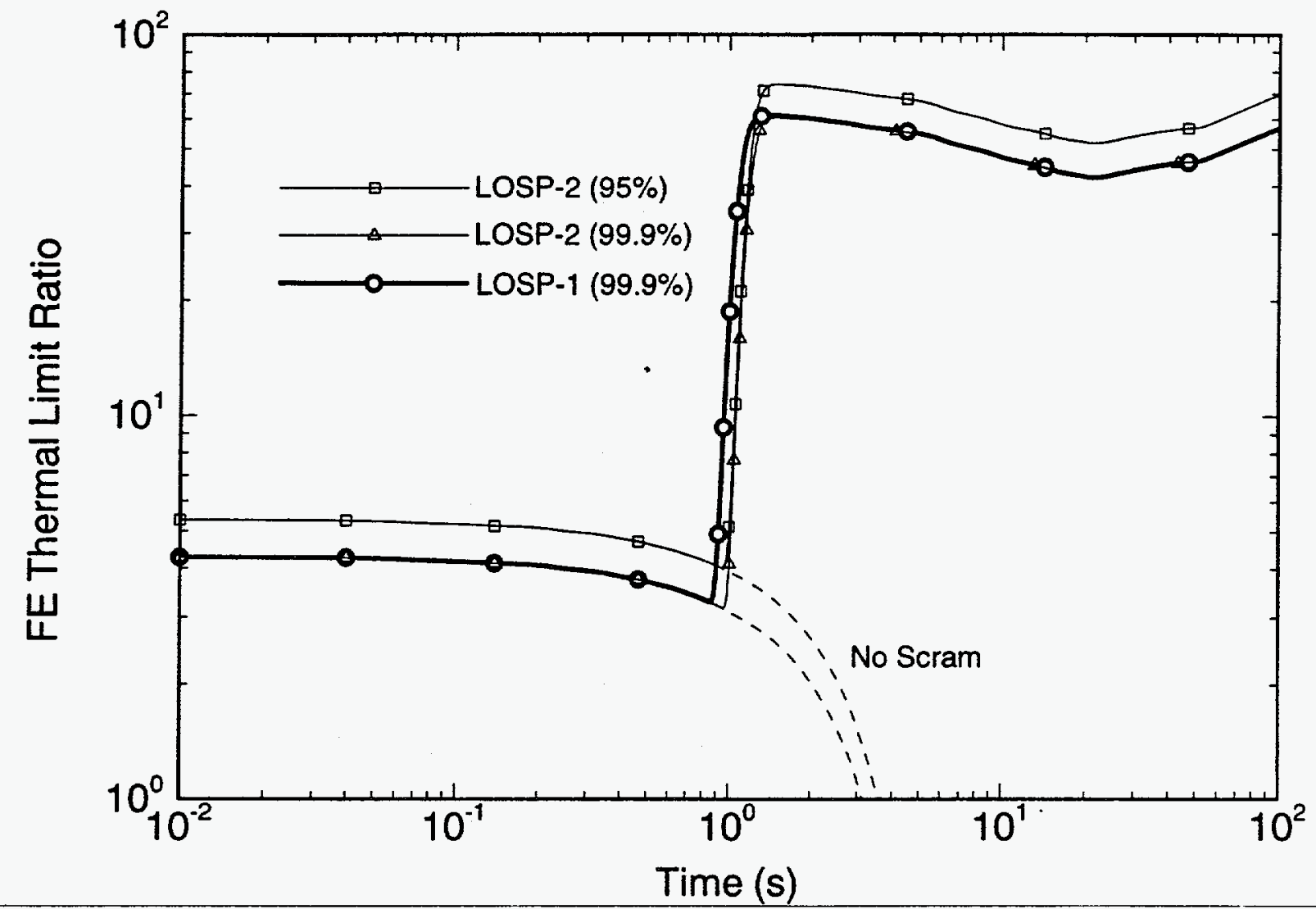

Fig. 10. Comparison of FE themal limit ratio at the lower fuel element $(99.9 \%$ nonexceedance probability) hot channel exit between LOSP-1 and LOSP-2 [LOSP-2 is a LOSP with no pre-scram control rod motion, normal (slow) letdown valve closure, and no secondary reactor shutdown system actuation; LOSP-2 is same as LOSP-1 except primary scram system fails and the secondary scram actuates as designed]. 
Table 5. Effects of scram delay time and nonexceedance probability on timing and magnitude of the first approach to thermal limit (LOSP-2).

\begin{tabular}{|c|c|c|c|c|}
\hline \multirow[t]{2}{*}{ Case } & \multirow[t]{2}{*}{$\begin{array}{c}\text { Nonexceedance probability for } \\
\text { combination of hot spot/streak } \\
\text { uncertainties }\end{array}$} & \multirow[t]{2}{*}{$\begin{array}{c}\text { Additional scram } \\
\text { delays, over and } \\
\text { above primary scram } \\
\text { system response time } \\
\text { (s) }\end{array}$} & \multicolumn{2}{|c|}{$\begin{array}{l}\text { Hot spot/streak thermal } \\
\text { limit ratio (CHF or FE) a } \\
\text { worst point }\end{array}$} \\
\hline & & & Time (s) & Magnitude \\
\hline LOSP-1 & $99.9 \%$ & 0. & 0.86 & 3.3 \\
\hline LOSP-2 & $95 \%$ & 0.1 & 0.96 & 4.0 \\
\hline LOSP-2 & $99.9 \%$ & 0.1 & 0.96 & 3.2 \\
\hline $\begin{array}{l}\text { Same as LOSP- } \\
2 \text {, but no scram }\end{array}$ & $95 \%$ & 2.62 & 3.58 & 1.0 \\
\hline $\begin{array}{l}\text { Same as LOSP- } \\
2, \text { but no scram }\end{array}$ & $99.9 \%$ & 2.16 & 3.12 & 1.0 \\
\hline
\end{tabular}

Thatio of 1.0 is lowest acceptable value.

\subsubsection{Margins Assessment}

If all scrams and other mechanisms for control rod insertion were to fail, the $95 \%$ nonexceedance probability thermal limit would be exceeded $3.58 \mathrm{~s}$ after the LOSP. If just the primary scram system fails, the outer control rods begin insertion at $0.96 \mathrm{~s}$. Hence there is a margin of $2.62 \mathrm{~s}(3.58-0.96=2.62)$ delay before the $95 \%$ nonexceedance probability thermal limit is exceeded. At $99.9 \%$ probability, the margin is reduced to $3.12-0.96$ $=2.16 \mathrm{~s}$. Thus the secondary scram system provides a very wide margin between the worst conditions reached and the minimally acceptable hot spot or streak conditions.

\subsection{LOSP-3: WORST CASE FOR TRANSITION TO NATURAL CIRCULATION}

The worst case for transition to natural circulation (LOSP-3) is the same as the certification basis case (LOSP-1) except that the diesel engines do not start, off-site power is not recovered, and the primary system depressurizes totally before the pony motor batteries are exhausted. The objective of the worst case is to verify transition to natural circulation under a total primary system depressurization. This worst-case scenario is categorized as an extremely unlikely event; hence the assessment of safety margin was performed against $95 \%$ nonexceedance probability CHF/FE limits. 


\subsubsection{Selection of Limiting Cases}

See Sect. 15.2.5.1 for the rationale behind the selection of LOSP-3.

\subsubsection{Input Data and Modeling Assumptions}

The input data set was created and saved on tape as LOSP3in.3el. In the model, the three letdown valves were gradually opened to the full-open position. The goal of this assumption is to achieve a total depressurization of the primary system (so that the pressure in the primary system is equal to that in the letdown tank) before the pony motor batteries are exhausted at $1800 \mathrm{~s}$, the assumed battery lifetime.

\subsubsection{Results}

The sequence of events for the worst case (LOSP-3) is listed in Table 6.

Since the stated objective of the LOSP-3 is to verify transition to natural circulation under a total primary system depressurization, the calculations were extended beyond the certification basis case up to $2500 \mathrm{~s}$ to obtain a significant period of response after the transition. To achieve a total system depressurization, three cases were calculated to examine the effects of system depressurization rate on the safety margin. First, one letdown valve was assumed to be stuck open at its normal position, but results showed that the system did not fully depressurize before $1800 \mathrm{~s}$. Second, three letdown valves were assumed to be stuck open at the normal positions; the system depressurized further but not totally. Third, three letdown valves were gradually opened to the full-open position, where the system pressure finally reached the letdown tank pressure by $1800 \mathrm{~s}$. Only the more pertinent thermalhydraulic responses of the third case are shown in Figs. 1 la through $1 \mathrm{lb}$, with the parameters important to natural circulation emphasized.

In the early transient, the total core flow (see Fig. 11) behaves the same as the certification basis case. After the pump ac (main) motor coasts down to pony motor speed, the total core flow remains constant until $1800 \mathrm{~s}$, when the batteries are exhausted. Thereafter, the pony motors start to coast down and the flow decreases to a minimum of $27 \mathrm{~kg} / \mathrm{s}$ at the transition point to natural circulation over a duration of about $20 \mathrm{~s}$ as determined by the RELAP5 torque balance equation (see expanded time scale of Fig. 12). At the transition point, the temperature rise across the core reaches its maximum so that natural circulation starts to initiate.

Once induced, the flow continues to increase and overshoots slightly the steady-state value reached several minutes later.

The temperature transient is shown in Fig. 13. The timing and magnitude of the first peak in coolant bulk and fuel surface temperatures prior to reactor scram is, of course, the same as the certification basis case. After the batteries expire, the pumps begin coasting down from pony motor speed, and a second, but less elevated, peak in these temperatures is seen because of lower flow conditions.

The system depressurizes at a relatively fast rate during LOSP-3 because of the greater extent of open letdown valves (i.e., as compared to LOSP-1 and -2 , which feature letdown valve closing over the first $8 \mathrm{~s}$ following the LOSP). The core outlet pressure (see Fig. 14) declines from nominal to about $0.3 \mathrm{MPa}$ (i.e., letdown tank pressure of $0.1 \mathrm{MPa}$ plus $0.2 \mathrm{MPa}$ of static head because the core outlet is approximately $18 \mathrm{~m}$ lower in elevation) as a result of losing coolant through the letdown valves. 
Table 6. Sequence of events for the worst case (LOSP-3)

\begin{tabular}{|c|c|}
\hline Time (s) & Event \\
\hline 0.00 & Diesel electric generators fail to start and remain inoperative for the entire $2500 \mathrm{~s}$ \\
\hline 0.00 to 9.1 & Events during this time period remain the same as Table 3 \\
\hline 9.34 & $\begin{array}{l}\text { Pressure at sensor location decreases below set point of } 1.40 \mathrm{MPa}(20 \% \text { below the } \\
\text { nominal) }\end{array}$ \\
\hline 100.0 & $\begin{array}{l}\text { Primary coolant pumps equilibrate at pony motor speed }(\sim 10 \% \text { of main motor } \\
\text { speed) }\end{array}$ \\
\hline 1800.0 & All pony motor batteries depleted, coastdown begins \\
\hline 1830.0 & Total core flow reaches a minimum of $27 \mathrm{~kg} / \mathrm{s}$ \\
\hline 1840.0 & $\begin{array}{l}\text { Costa FE thermal limit ratio reaches a second minimum of } 21 \text { (smallest acceptable is } \\
1.0 \text { ) }\end{array}$ \\
\hline 1840.0 & Temperature rise across the core reaches a maximum of $61 \mathrm{~K}$ \\
\hline 2480.0 & Natural circulation fully established with a flow of $40 \mathrm{~kg} / \mathrm{s}$ \\
\hline 2500.0 & $\begin{array}{l}\text { Pressure at the main heat exchanger inlet where the letdown line is connected has } \\
\text { decreased to approximately the letdown tank pressure }\end{array}$ \\
\hline 2500.0 & Letdown valves remain fully open with a total flow of $2.9 \mathrm{~kg} / \mathrm{s}$ \\
\hline 2500.0 & Calculation stopped \\
\hline
\end{tabular}

A consistent trend is displayed in the inventory related mass flows (Fig. 15). Opening up the letdown valves causes the total letdown flow to increase and then decrease as the pressure differential between the system and the letdown tank gets smaller. In response to enhanced flow to the letdown tank, the accumulators inject strongly for a significant period. Even though the liquid levels in each accumulator (see Fig. 16) drop significantly from that of the certification basis case where the liquid levels are hardly changed, the accumulators are not completely drained at the end of calculation ( $2500 \mathrm{~s}$ ). The design basis for the accumulators is that they should not be completely drained by a primary coolant system depressurization.

The thermal limit ratio occurring at the lower fuel element $95 \%$ hot channel is shown in Fig. 17, wherein the two closest approaches to the thermal limits exist. As mentioned earlier, the first closest approach occurs during the transition from full power to decay heat, and the second one occurs during transition from pony motor forced circulation to natural circulation. The timing for the first closest approach remains the same as LOSP-1, but the magnitude is higher ( 4.2 vs 3.3 ) since the LOSP-1 is calculated against a $99.9 \%$ nonexceedance probability. The magnitude of the second closest approach (about 21), occurring at $1840 \mathrm{~s}$, is higher than the first one because of diminishing decay heat under natural circulation conditions.

The parameters pertinent to calculations of the Costa FE heat flux limit are shown in Figs. 18 and 19 for both short and long time scales. As stated earlier, at high power, high pressure, and high flow, the greatest contributor toward exceeding the limit is the local subcooling. This fact remains true for the conditions at low power, low pressure, and low velocity; however, the velocity contribution toward exceeding the limit becomes more 
important as the flow continues to diminish, in particular at the transition to natural circulation. At the transition point, the minimum velocity and subcooling maintain about $0.3 \mathrm{~m} / \mathrm{s}$ and $44 \mathrm{~K}$, respectively.

\subsubsection{Margins Assessment}

At transition to natural circulation, the minimum value of the thermal limit ratio is at 20 or greater, indicating that the heat flux would have to be increased by a factor of more than 20 to initiate voiding. However, the minimum coolant velocity reaches about $0.3 \mathrm{~m} / \mathrm{s}$, which is outside of the Costa correlation experimental data range ( 2 to $7 \mathrm{~m} / \mathrm{s}$ ), raising the issue of the applicability of the Costa correlation under such low flow conditions. A preliminary flow excursion data comparison indicates that the Costa-predicted heat flux limit in the low flow range is higher than existing data, calling into question the very large calculated FE margins. Hence, other factors not dependent upon the Costa correlation, must be considered for this event.

RELAP5 predictions as shown in Fig. 12 imply that neither the coolant nor the fuel surface reach saturation temperature; at the worst point during the transition, the bulk coolant temperature is about $44 \mathrm{~K}$ below saturation, and the fuel surface is about $24 \mathrm{~K}$ below saturation, which would indicate no boiling at the fuel plate surface, and therefore the FE limit could not be exceeded, based only upon physical principles. However, the single-phase heat transfer coefficients used by RELAP5 under these conditions appear to overpredict the local heat transfer and therefore would underpredict the local surface temperature. The amount of underprediction is presently under study. Since we do not expect that all pumps will trip at one time (or will design so that they do not) and that the uncertainty levels that are currently used for single-phase heat transfer are somewhat conservative, we believe that the $T_{\text {wall }} \leq T_{\text {sat }}$ criterion-a more conservative criterion than the no FE- or CHF-based criteria-may be achievable.

Additional calculations (not shown here) have demonstrated that the transition to natural circulation is sensitive to the pony motor coastdown time, system depressurization, and battery lifetime. Earlier than $1800 \mathrm{~s}$ in the transient, the decay heat is higher and the margin to the thermal limits is less. RELAP5 calculations have predicted that even without pony motors at all, this transition would occur successfully as long as the system pressure is maintained. In the event of a depressurization, such as that occurring with a pipe break, if the pony motors last for at least 5 minutes, then the transition will occur without exceeding the thermal limits. 


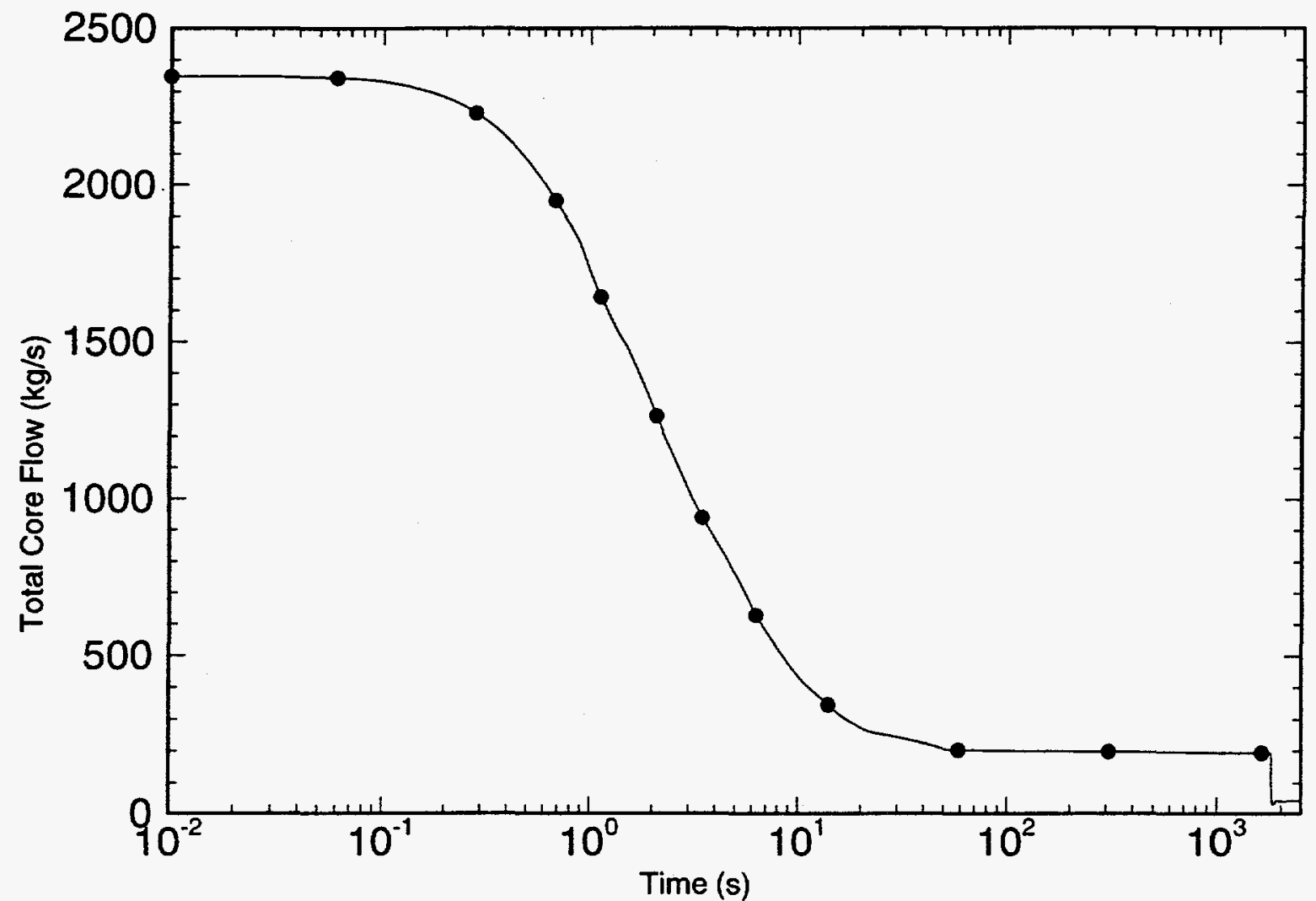

Fig. 11. Total core flow transient during LOSP-3 (extended LOSP with diesel generator failure and gradually opened letdown valves to accomplish total primary system depressurization before the pony motor batteries are exhausted). 


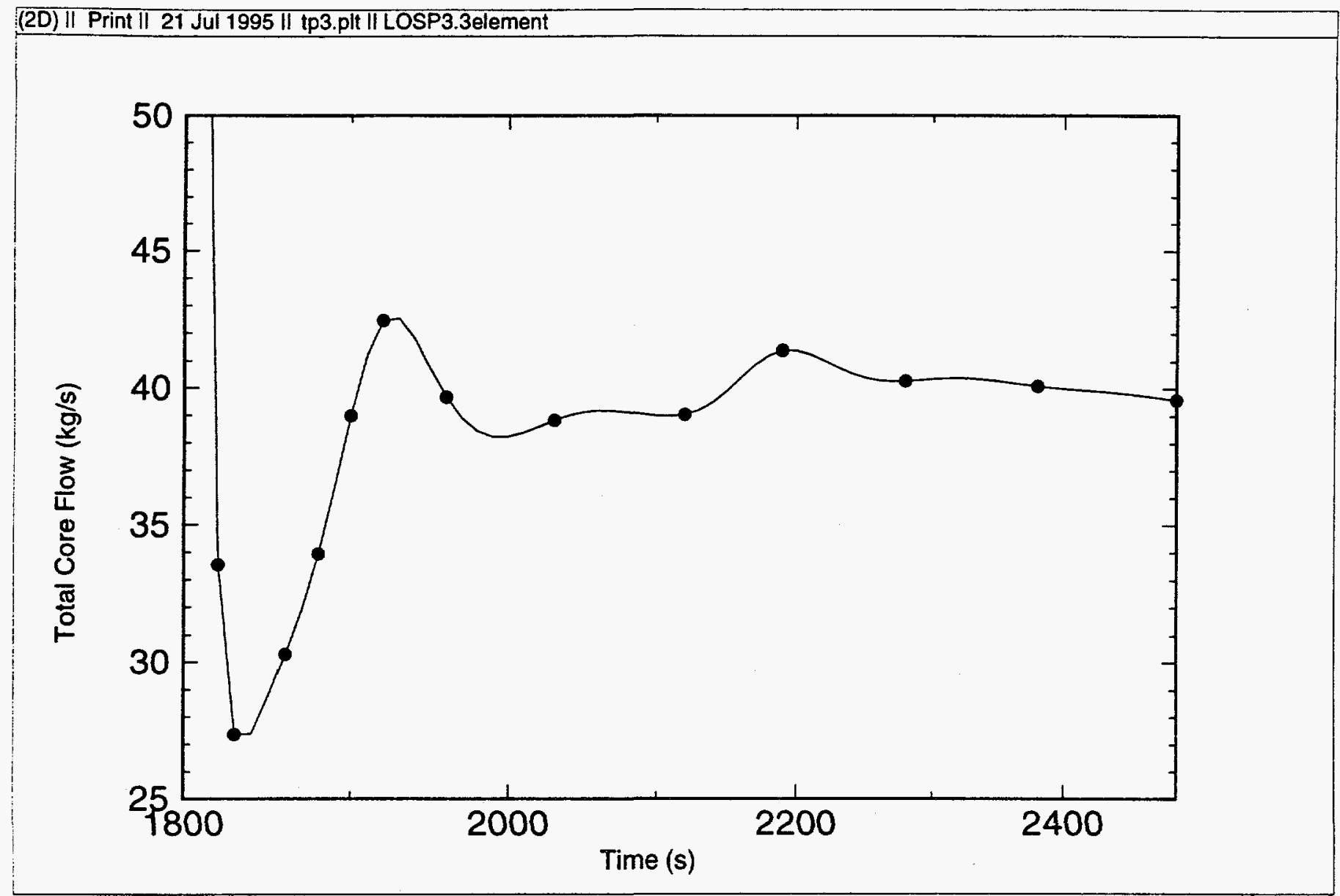

Fig. 12. Closeup of total core flow transient after pony motor coastdown during LOSP-3 (extended LOSP with diesel generator failure and gradually opened letdown valves to accomplish total primary system depressurization before the pony motor batteries are exhausted). 


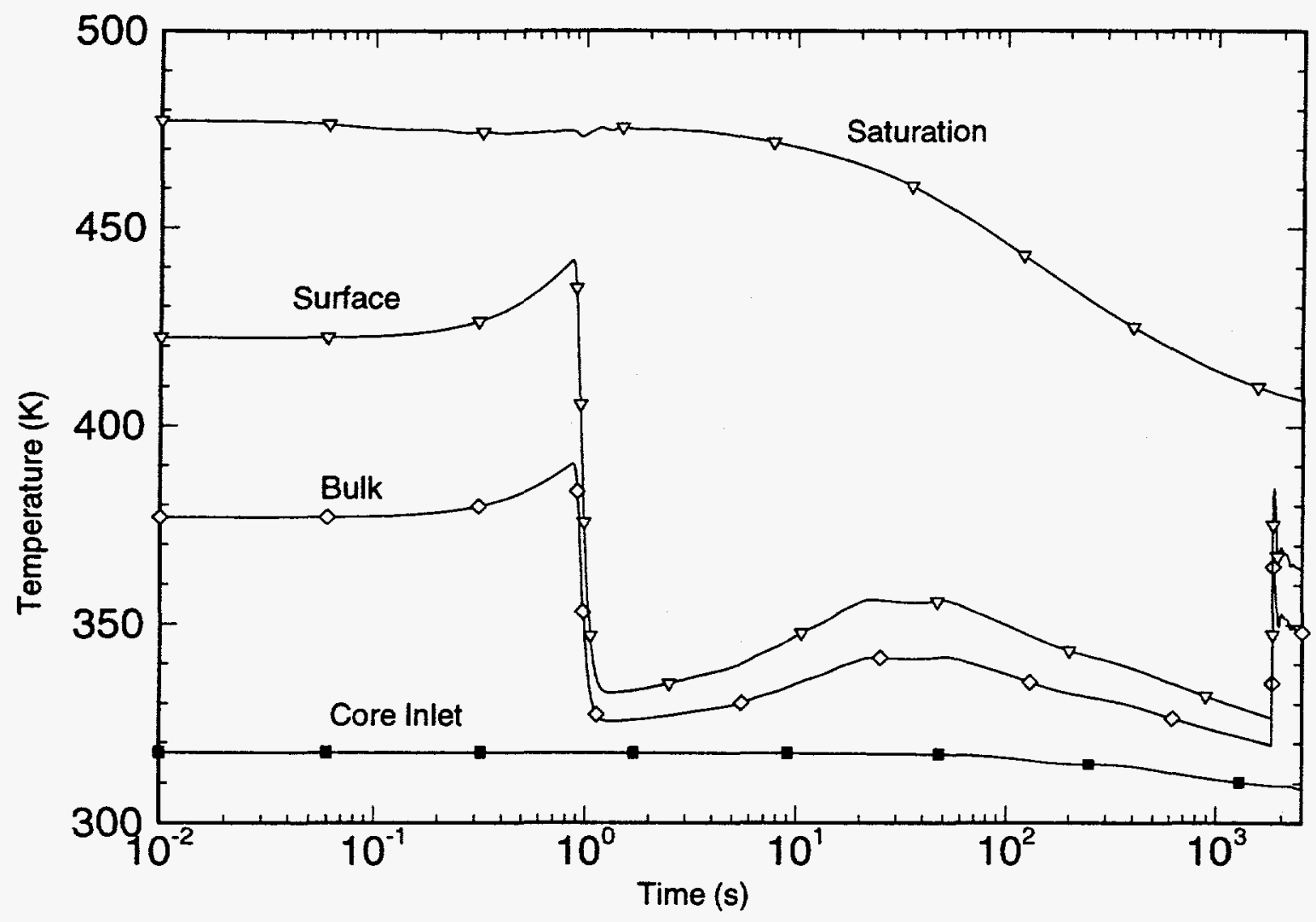

Fig. 13. Temperature response at the lower fuel element $95 \%$ hot channel exit in reference to the core inlet temperature during LOSP-3 (extended LOSP with diesel generator failure and gradually opened letdown valves to accomplish total primary system depressurization before the pony motor batteries are exhausted). 


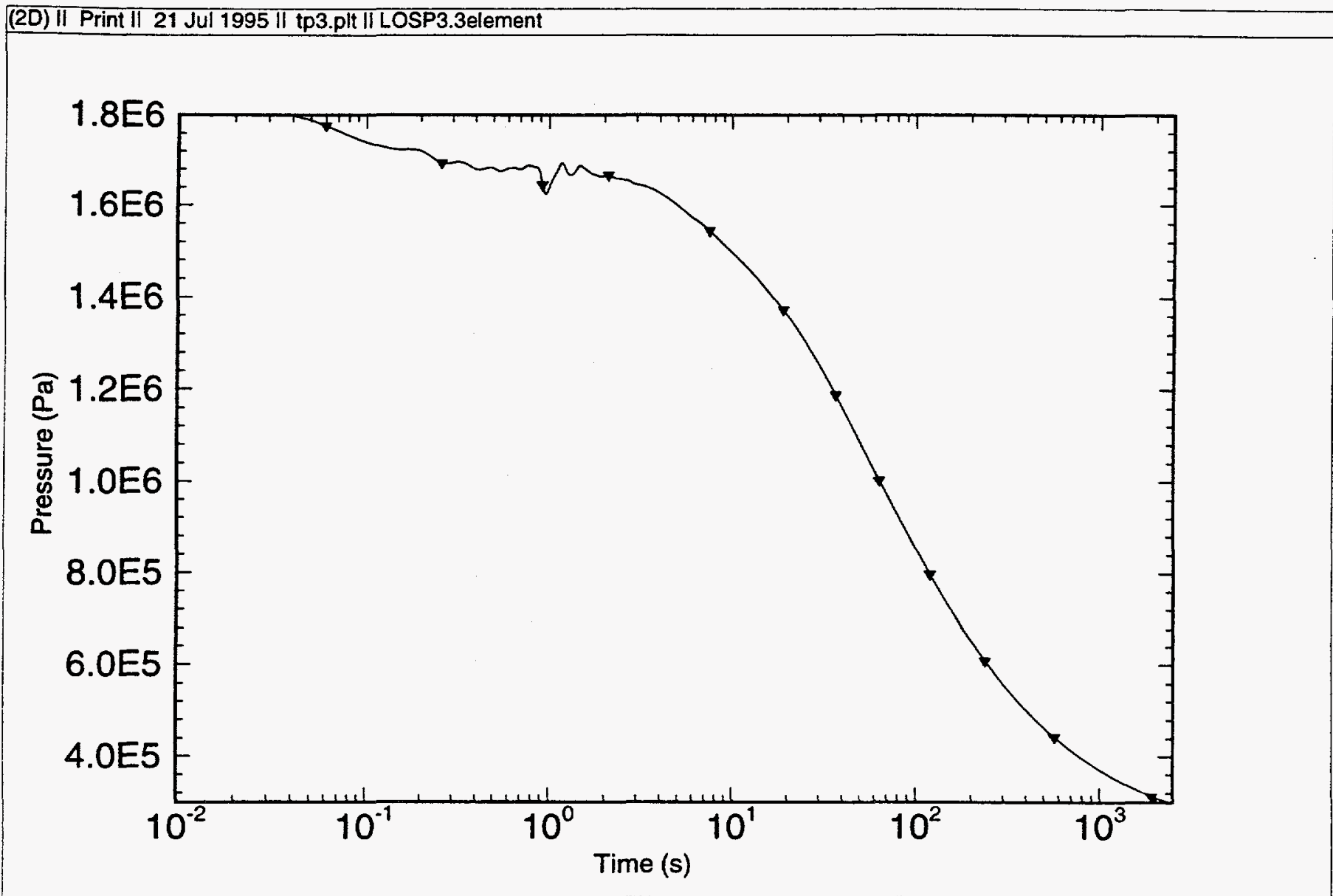

Fig. 14. Pressure at the lower fuel element $95 \%$ hot channel exit during LOSP-3 (extended LOSP with diesel generator failure and gradually opened letdown valves to accomplish total primary system depressurization before the pony motor batteries are exhausted). 


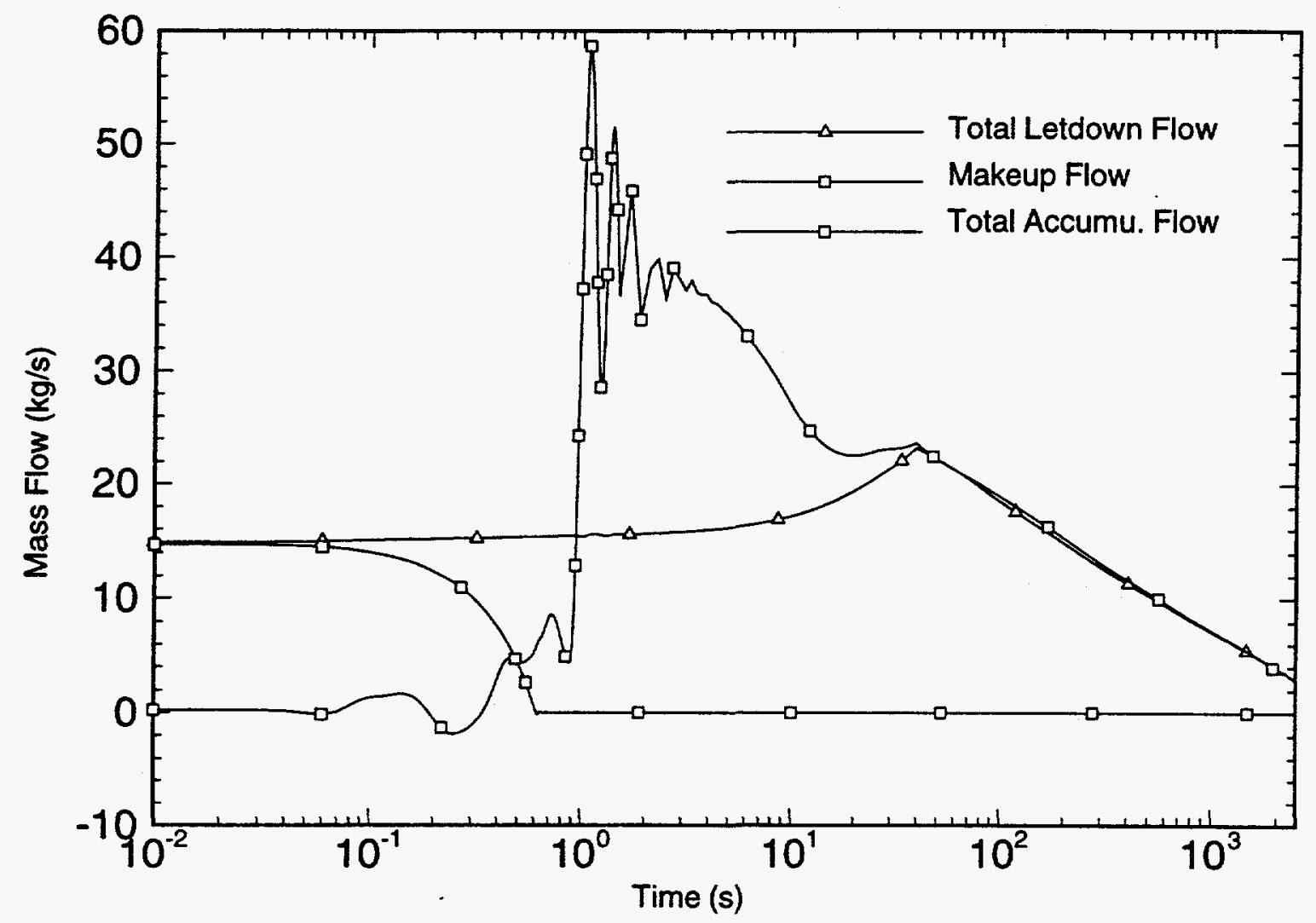

Fig. 15. Total letdown, makeup, and total accumulator flow during LOSP-3 (extended LOSP with diesel generator failure and gradually opened letdown valves to accomplish total primary system depressurization before the pony motor batteries are exhausted). 


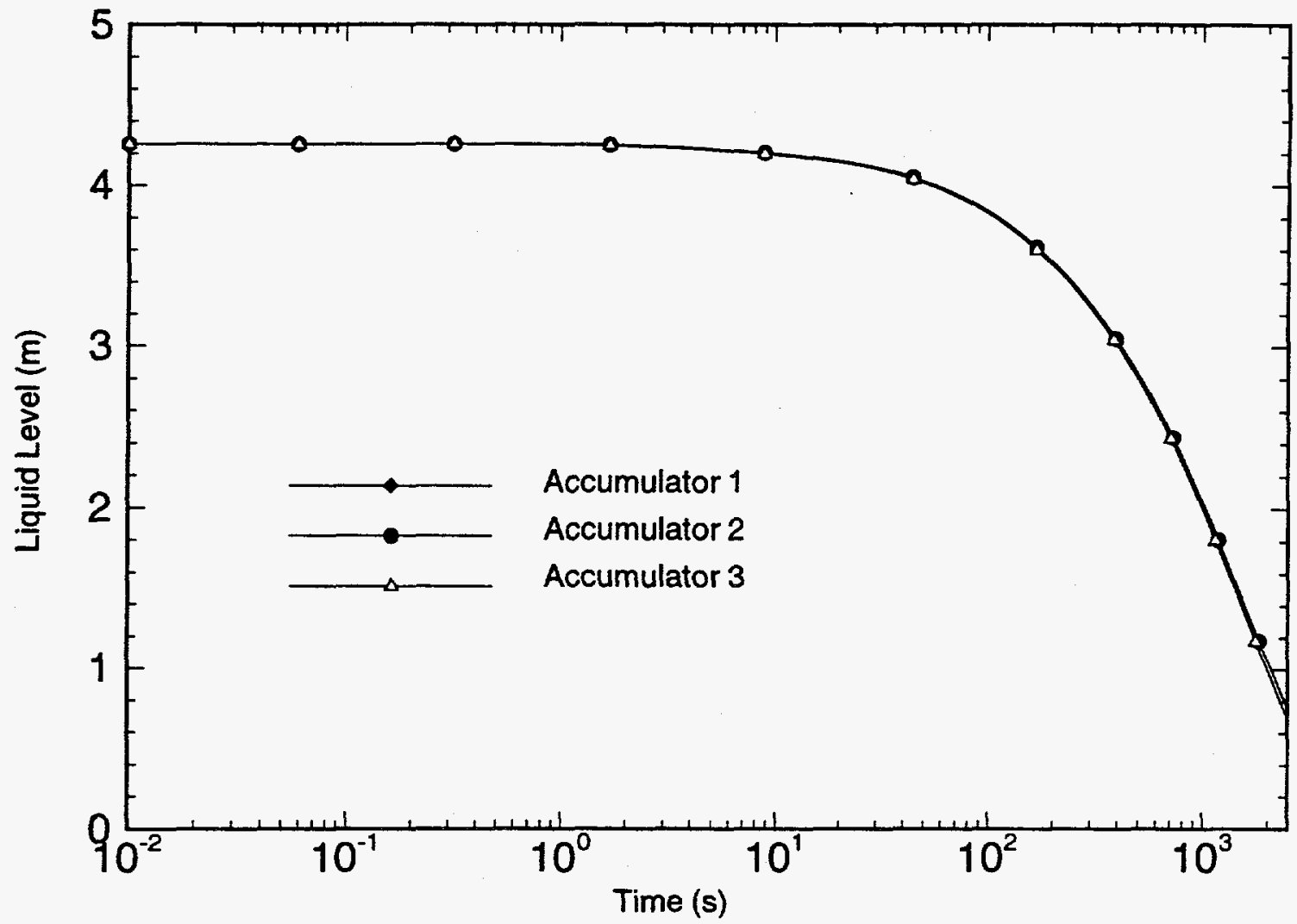

Fig. 16. Liquid level within each accumulator during LOSP-3 (extended LOSP with diesel generator failure and gradually opened letdown valves to accomplish total primary system depressurization before the pony motor batteries are exhausted). 


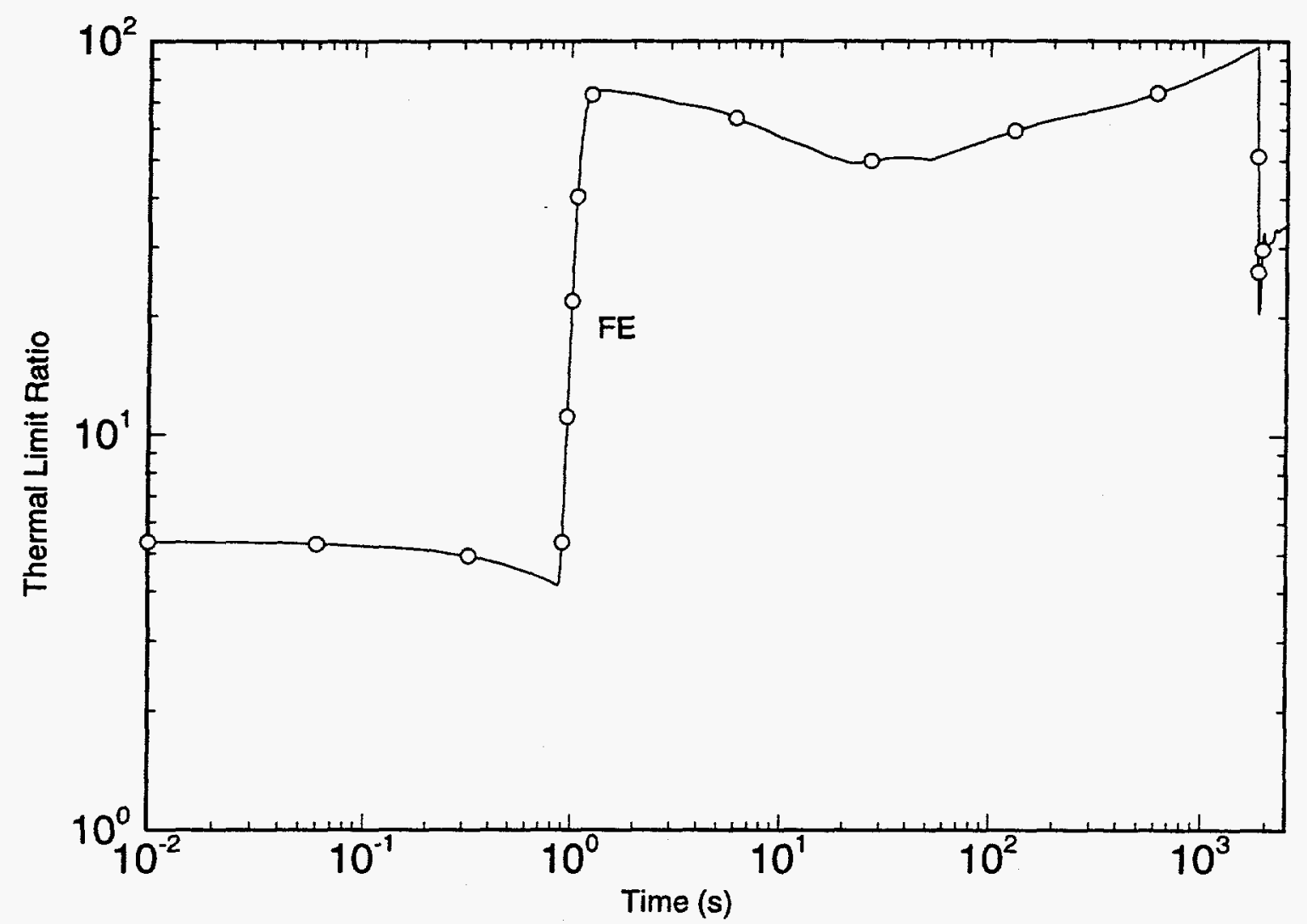

Fig. 17. Comparison of FE and CHF thermal limit ratio minima at the lower fuel element (95\% nonexceedance probability) hot channel exit during LOSP-3 (extended LOSP with diesel generator failure and gradually opened letdown valves to accomplish total primary system depressurization before the pony motor batteries are exhausted). 


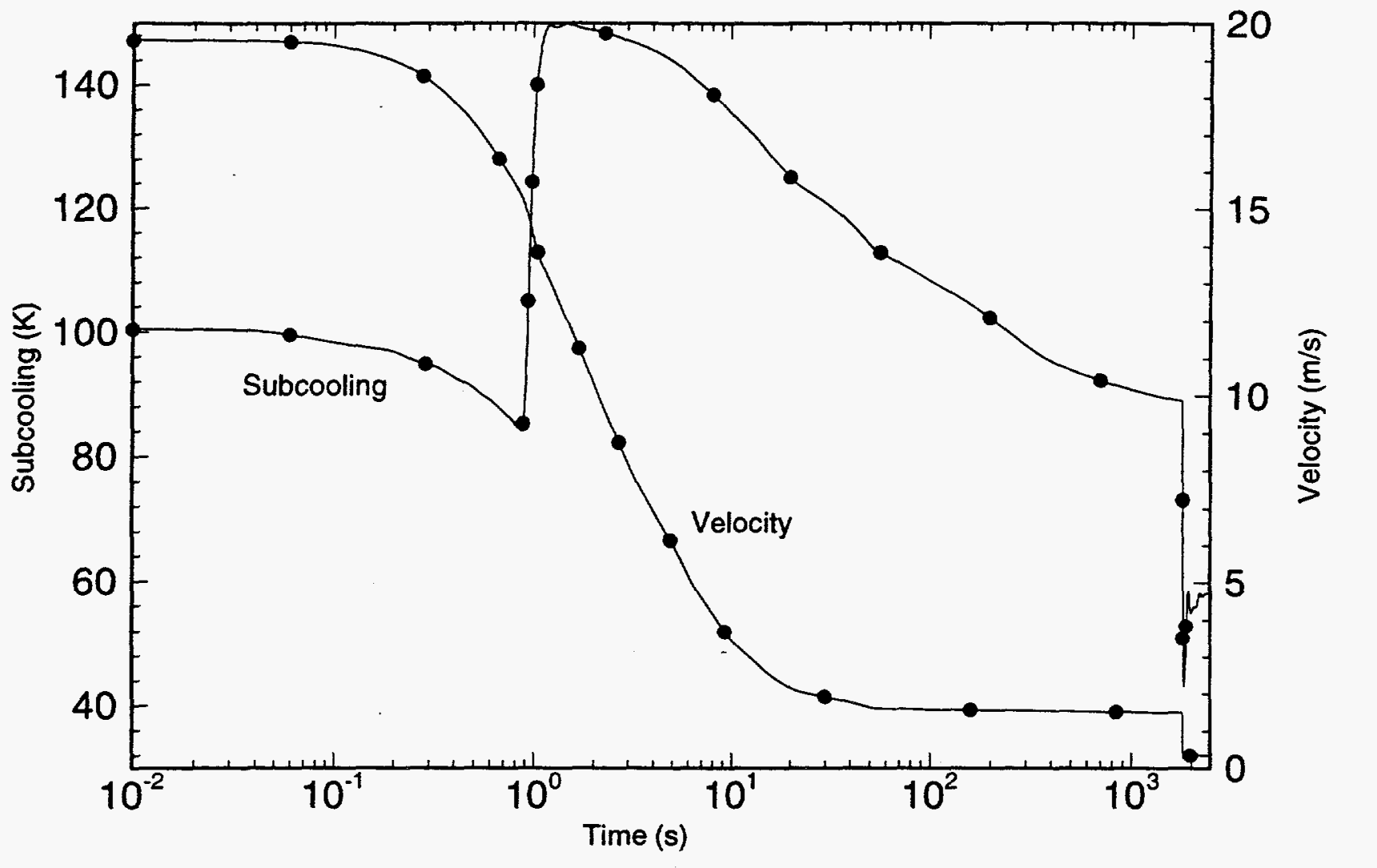

Fig. 18. Parameters pertinent to the Costa limiting heat flux calculations during LOSP-3 (extended LOSP with diesel generator failure and gradually opened letdown valves to accomplish total primary system depressurization before the pony motor batteries are exhausted). 


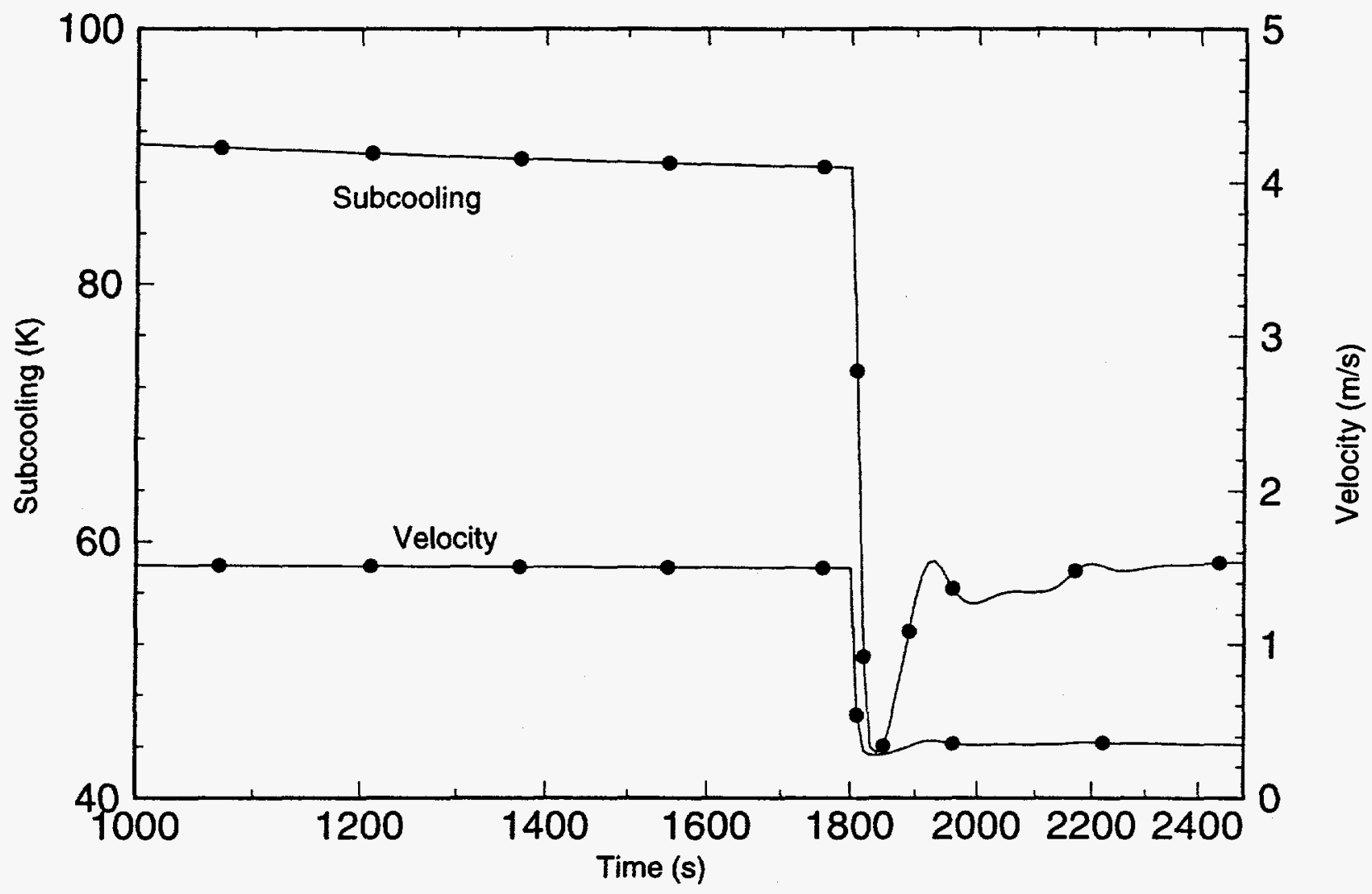

Fig. 19. Closeup for parameters pertinent to the Costa limiting heat flux calculations during LOSP-3 (extended LOSP with diesel generator failure and gradually opened letdown valves to accomplish total primary system depressurization before the pony motor batteries are exhausted). 


\section{RAPID DEPRESSURIZATION ACCIDENTS}

This section presents the RELAP5 results for the loss-of-primary-coolant accident for the three-element-core configuration. Each accident simulated involves an instantaneous rupture in the primary pressure boundary at either the core inlet or core exit location. This results in a depressurization of the system and loss of primary coolant $\left(D_{2} O\right)$ to the light-water pool. Although the accumulators inject $\mathrm{D}_{2} \mathrm{O}$ in response to the depressurization, they cannot respond quickly enough to mitigate the acoustic wave that immediately follows the instantaneous break.

\subsection{SELECTION OF LIMITING CASES FOR PRESSURE BOUNDARY FAULT}

The selection of limiting cases for the pressure boundary fault is identical to that for the two-element core analysis described in the CSAR update. ${ }^{1}$

\subsection{INPUT DATA AND MODELING ASSUMPTIONS}

RELAP5/MOD3.1.1.1 (which includes the ANS updates described in Sect. 15.0.4 of the 1992 CSAR issue) was used to perform the three-element-core LOCA simulations. A fine discretization comparable to that used in the updated two-element-core analysis was defined.

The three element core model was constructed by modifying the two-element-core model in the core region only, in order to create three parallel-core flow paths instead of two, as well as three sets of fuel heat structures instead of two. The hot- and cold-leg piping, pumps, heat exchangers, and accumulators are identical to that assumed in the two-element core model. The geometry and operating conditions of the three-element core were presented in the January 1995 ANS Monthly Progress Report. The outer and inner elements are on the same axial level, but the middle element is lower. The nodalization diagram for the three-element core is shown in Fig. 1. The name of the input file for the three-element-core model is rfd50195in.

\subsection{RESULTS}

Although in the actual RELAP5 simulation the pipe break is initiated $10 \mathrm{~s}$ into the transient, the initial $10 \mathrm{~s}$ is subtracted for those times presented in this section, so that the pipe break is presented as occurring at time 0 in the tables and figures.

The first case discussed assumes that a 76-mm (3.0-in.)-diam hole forms instantaneously at the core inlet location (just upstream of the PSVAW in one of the cold legs). The middle fuel element is the most limiting element for this transient. The sequence of events for this transient is shown in Table 7.

The pressure at the core exit plane just inside the middle fuel element hot fuel channel is shown in Fig. 20. The complex acoustic wave form passing the core exit location before $0.1 \mathrm{~s}$ is a result of transmissions and reflections of acoustic energy at various junctions and flow-area changes within the system. It takes a pressure wave about 
$0.1 \mathrm{~s}$ to complete the loop around the primary coolant system. After about $0.1 \mathrm{~s}$, the accumulator starts to affect the core outlet pressure. The system depressurizes down to the reactor pool pressure as the primary pumps coast down and the accumulators are drained. The reactor power declines after scram as shown in Fig. 21. 


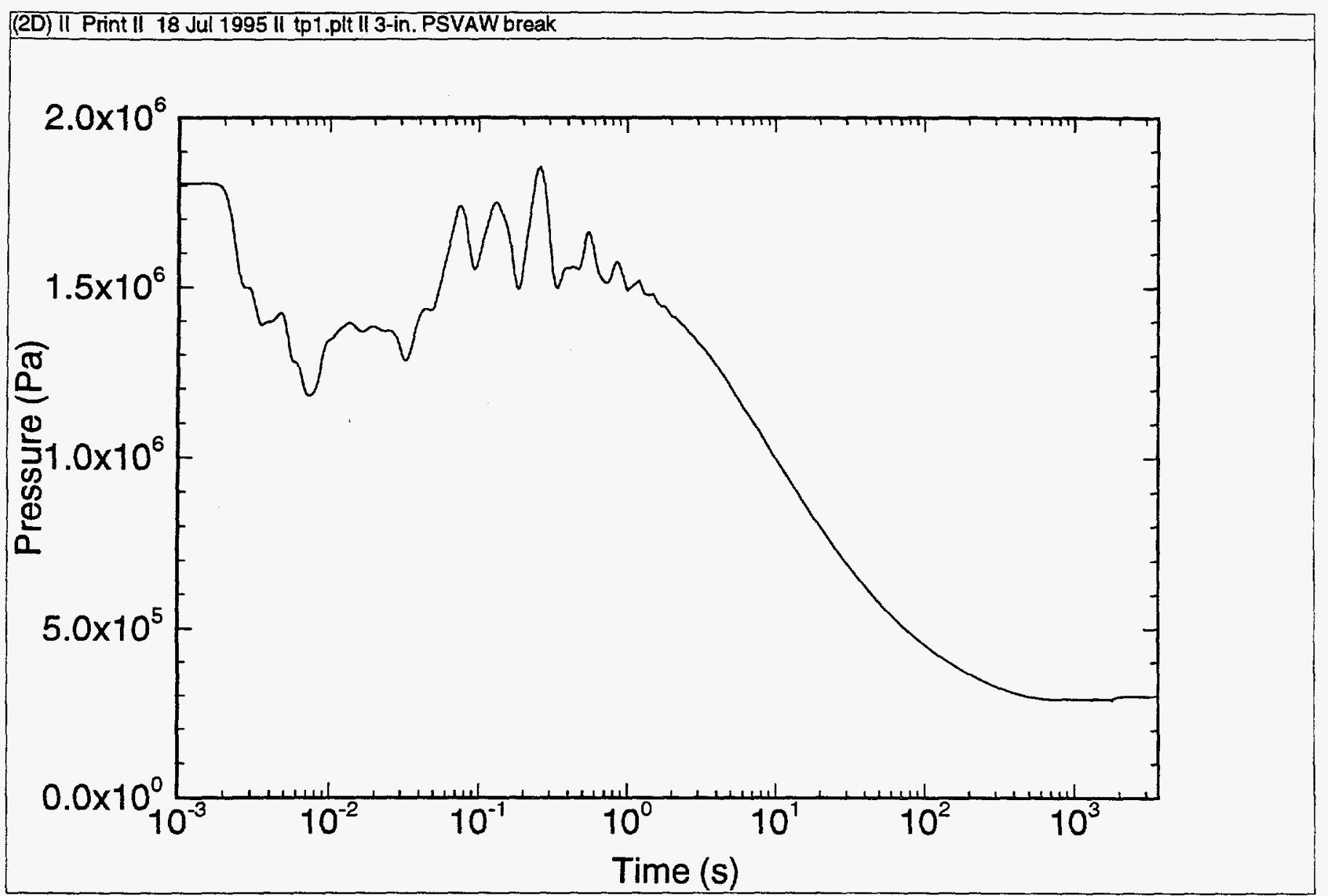

Fig. 20. Core exit pressure during a 76-mm (3-in.)-diam instantaneous core inlet pipe break with coincident LOSP for the three-element-core configuration. 


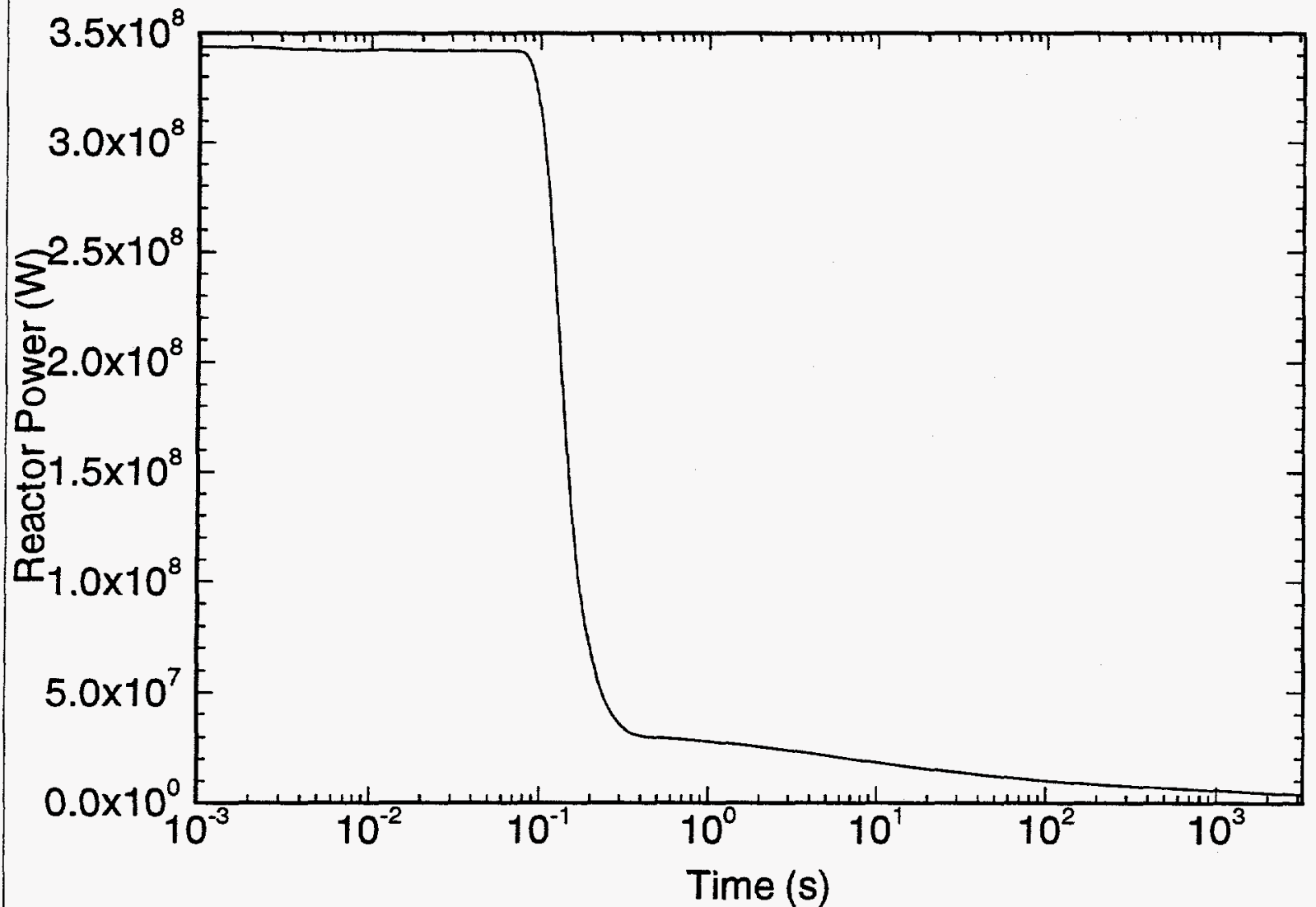

Fig. 21. Reactor power decay during a 76-mm (3-in.)-diam instantaneous core inlet region pipe break with coincident LOSP for the three-element-core configuration. 
The combined accumulator flows, break flow and total core flow are shown in Fig. 22. The total core flow is affected by three factors: (1) the primary pump action, which tends to increase core flow; (2) the accumulator injection to compensate for lost break flow (the larger the pipe break, the larger effect this factor will have), which tends to decrease the core flow; and (3) the buoyancy forces and higher temperatures generated by the decay heat, which tend to increase the core flow. During the first $800 \mathrm{~s}$ of the transient, each of these factors diminishes and the effect of decreasing accumulator flow competes with the effects of decreasing pump speed and decay heat. The total core flow begins to drop first because the pump is coasting down. Although the pump does not coast all the way down to the $10 \%$ pony motor speed until $100 \mathrm{~s}$, the total core flow reaches a minimum at $54 \mathrm{~s}$ and begins to increase because of the declining accumulator flow, which is pushing less and less against the normal flow direction. Once the accumulator has emptied at $750 \mathrm{~s}$, the only one of the three core-flow factors that is still changing is the decay heat level; hence the core flow begins slowly to decline with the reactor power level. At $1800 \mathrm{~s}$, the pony motor batteries expire causing the primary coolant pumps to shut down altogether. After a short transition period from forced to natural circulation, the primary flow begins a slow, steady decline starting at 36 $\mathrm{kg} / \mathrm{s}(0.46 \mathrm{~m} / \mathrm{s}$ in the fuel channels $)$.

The break flow is a function only of the core inlet pressure and therefore declines with the depressurization. The accumulators are perturbed initially by the sudden depressurization following the pipe break and respond with an oscillatory mass injection. However, the accumulator flow oscillations are quickly (within $3 \mathrm{~s}$ ) and completely dampened, and the flow from the accumulator into the primary system stabilizes to match the flow out of the system through the pipe break. Thereafter, the break and accumulator flows decline in unison until they are both zero when the primary system has reached pool pressure.

The $95 \%$ and $99.9 \%$ nonexceedance probability level thermal limits in the middle fuel element are presented in Fig. 23. The thermal limit ratio is defined as the ratio of hot-spot heat flux to limiting heat flux. Because it is expected that a larger surface area of the fuel plate would have to be involved to cause a flow excursion (i.e., FE is dictated by channel pressure drop), the CHF limit is more conservative here because it is applied on a more local basis than is the FE criterion. The Costa thermal limit criterion is most limiting at the 4th (out of five) axial node (node five being near the core exit). However, the CHF thermal limit is most limiting at the 5th (exit) node. The $95 \%$ nonexceedance probability CHF ratio is not shown in the figure because the hot spot wall temperatures did not exceed the saturation temperature, so RELAP5 did not calculate the CHF value.

As typical for an ANS LOCA, three minima are observed in the FE thermal limit: the first is caused by depressurization following the break; the second, because of decreasing core flow during pump coastdown; and the last, because of decreased core flow after the pony motor trip during the transition from forced to natural circulation in the primary circuit. The thermal limits are not violated at any of these minima for the design-basis 76-mm-diam inlet break.

Larger instantaneous pipe breaks have also been simulated at the core inlet location, and the thermal limits for these cases are presented in Figs. 24 and 25 . The thermal limits shown are for $95 \%$ nonexceedance probability at the most limiting hot spot. In Fig. 24, for the larger breaks (with diameters greater than $102 \mathrm{~mm}$ ) the exit hot spot (5th axial node) is most limiting, and for the 102-mm-diam break, the 4th axial node is most limiting. For CHF, the exit hot spot is always the most limiting.

Figure 25 is complicated by the sudden appearance and reappearance of the $102 \mathrm{~mm}$ CHF curve. When the hotspot surface temperature is less than the saturation temperature, RELAP5 does not calculate CHF, so a value of zero is output, giving also a thermal limit ratio of zero. Once the hot-spot surface temperature exceeds the 
saturation temperature, the CHF assumes a value, and the thermal limit ratio jumps from zero up to some finite value as shown in the figure between 0.004 and $0.006 \mathrm{~s}$. 


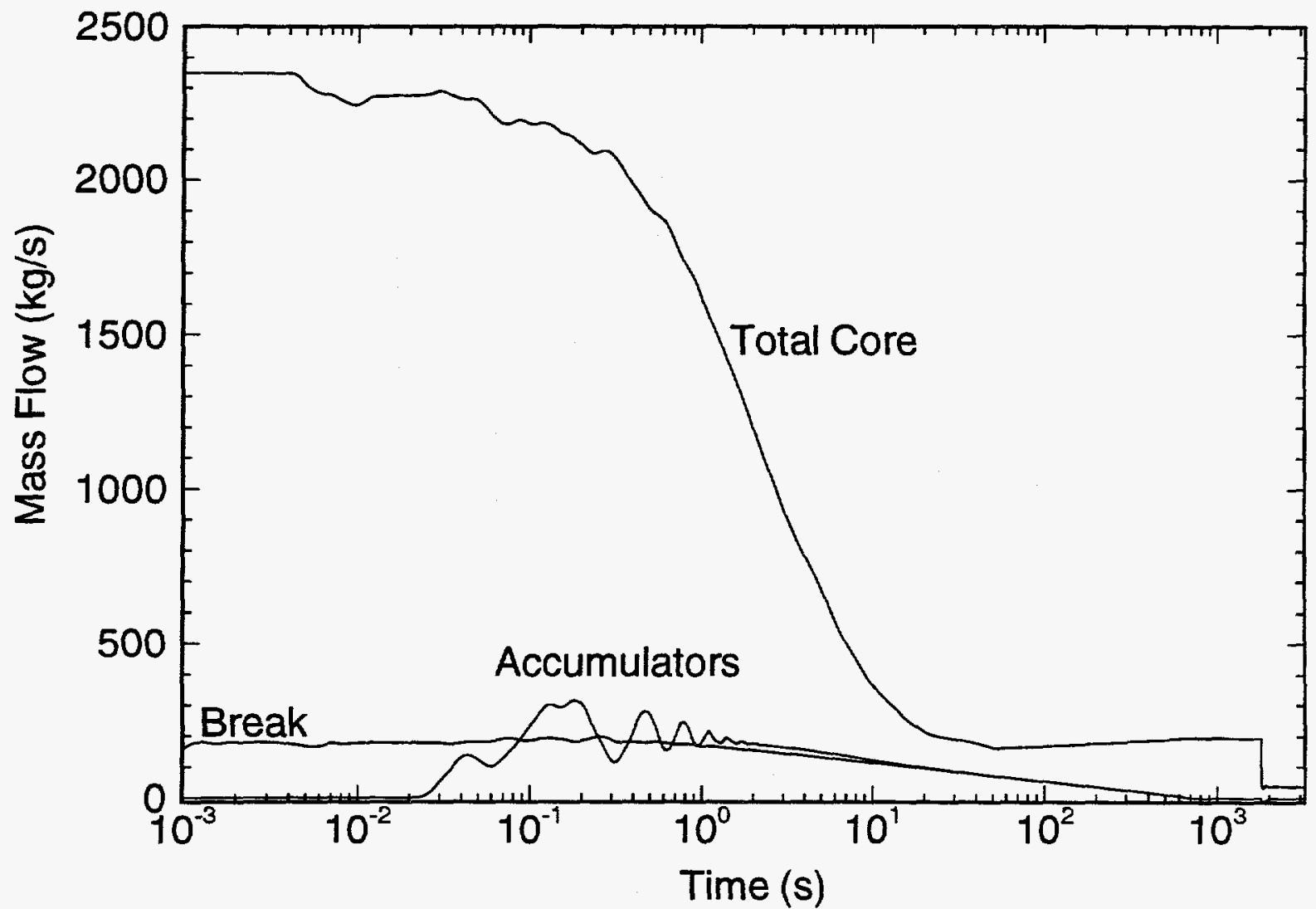

Fig. 22. Important mass flow rates during a 76-mm (3-in.)- diam instantaneous core inlet region pipe break with coincident LOSP for the three-element-core configuration. 


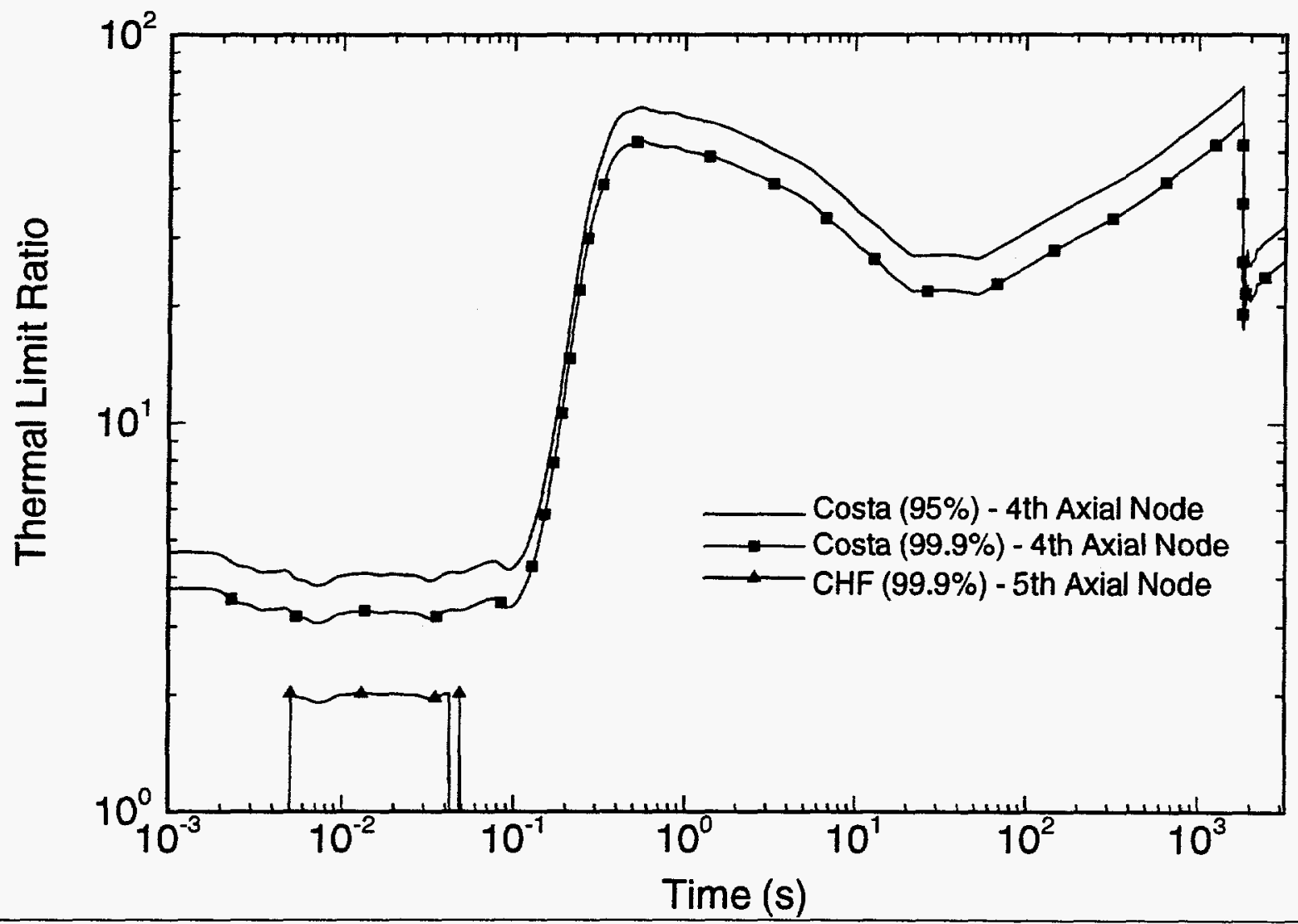

Fig. 23. Thermal limit ratios during a 76-mm (3-in.)-diam instantaneous core inlet region pipe break with coincident LOSP for the three-element-core configuration. 


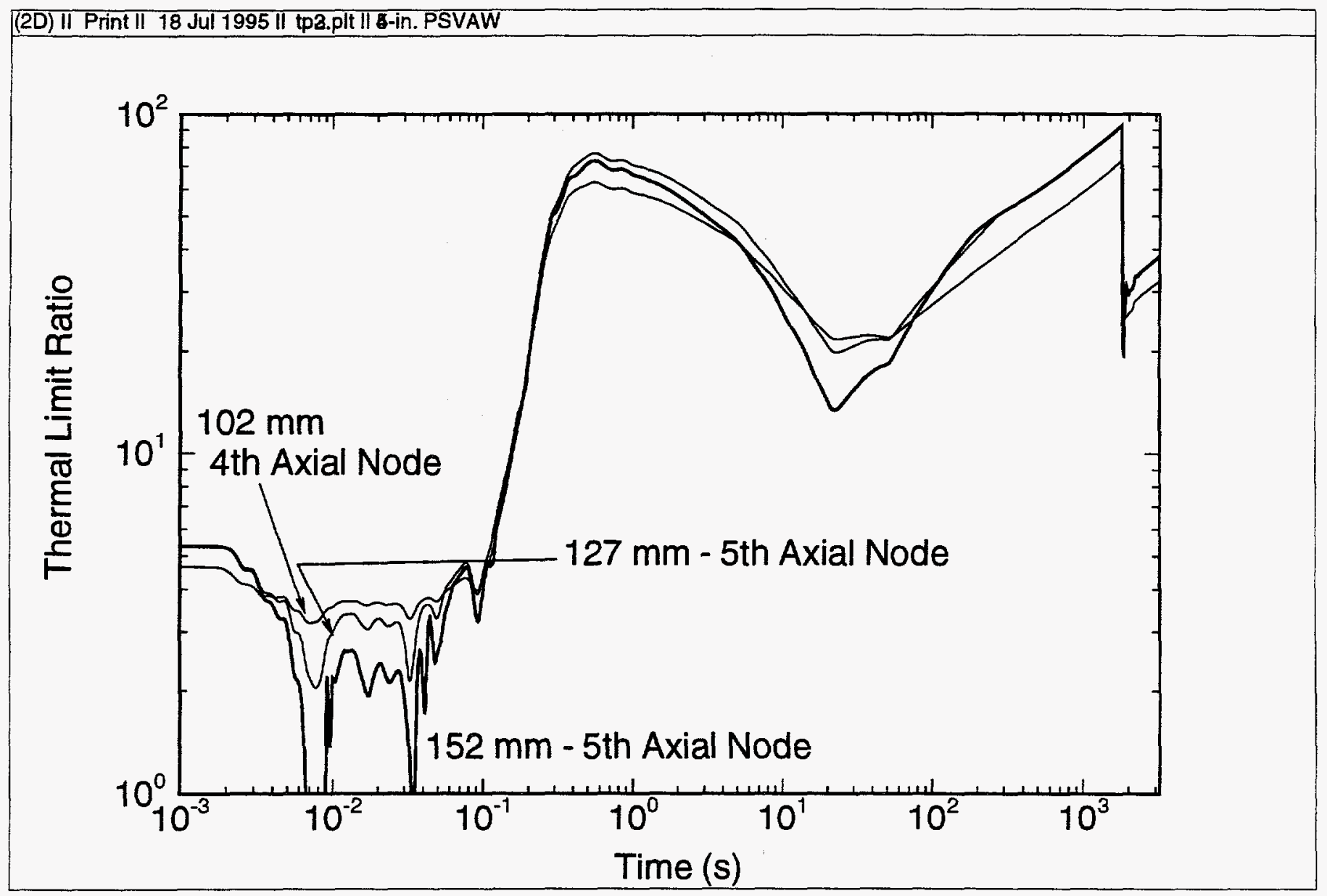

Fig. 24. FE thermal limit ratios for limiting break sizes for core inlet breaks with coincident LOSP for the three-element-core configuration. 


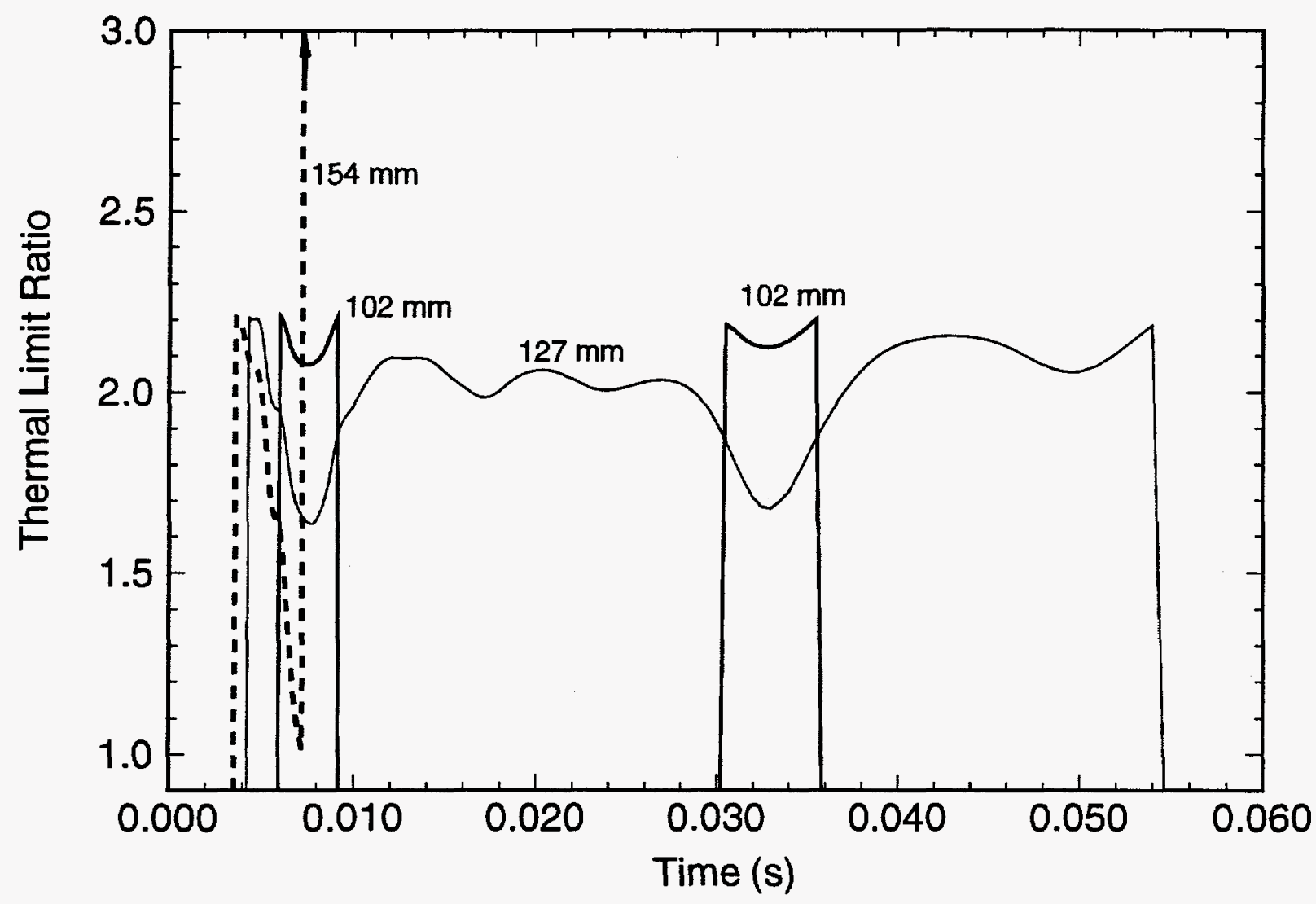

Fig. 25. CHF thermal limit ratios for limiting break sizes for core inlet breaks with coincident LOSP for the three-element-core configuration. 
Although the 127-mm (5-in.)-diam break does not result in violation of either thermal limit, the 152-mm (5in.)-diam break leads to violation of both $\mathrm{FE}$ and $\mathrm{CHF}$. The violation of the $\mathrm{CHF}$ limit is indicated for the 127-mm (5-in.)-diam break in Fig. 25 by the sudden increase in the thermal limit ratio immediately after the curve falls to a value of unity. The increase is because of the onset of film boiling, and, hence, very low heat transfer at the wall. The hot-spot fuel temperatures for this case increase rapidly, thus fuel damage would occur.

In addition to the core inlet breaks, instantaneous core outlet (hot-leg) breaks have been simulated to determine the limiting break sizes. Figure 26 indicates that the largest instantaneous, circular orifice break that can be sustained at the core exit without exceeding the flow excursion heat flux limit has a diameter of $152 \mathrm{~mm}$ ( 6 in.). Figure 27 indicates that the largest break that can be sustained without violating the CHF limit also has a diameter of $152 \mathrm{~mm}$ (6 in.). The sudden increase in CHF thermal limit ratio for the $178-\mathrm{mm}-$ diam break occurs as soon as film boiling begins (thermal limit ratio $=1.0$ ) and the surface heat flux becomes extremely small. For the core exit breaks, RELAP5 predicts that no void is generated at the exit of the $95 \%$ nonexceedance probability hot channel when the break diameter is $152 \mathrm{~mm}$ (6 in.).

\subsection{MARGINS ASSESSMENT}

For the design-basis-break diameter of $76 \mathrm{~mm}$ (3-in.), more than a factor of 2 margin exists between the hotspot heat flux and the thermal limit. During the most limiting part of the transient, the velocity remains about $20 \mathrm{~m} / \mathrm{s}$ and the subcooling drops to a minimum of $77 \mathrm{~K}$. The pressure reaches a corresponding minimum of $1.18 \mathrm{MPa}$. In order for the FE correlation to be violated, the pressure must fall to about 0.3 $\mathrm{MPa}$. Since the steady-state pressure at the core exit is $1.8 \mathrm{MPa}$, RELAP5 would have to underpredict the local depressuization at the fuel exit during the passage of the pressure wave by a factor of 2.42 . 
Table 7. Sequence of events for 76-mm (3.0-in.)-diam instantaneous pipe break near core inlet

\begin{tabular}{ll}
\hline Time $(\mathrm{s})$ & \\
\hline 0.000 & Pipe break at core inlet with coincident loss-of-off-site power \\
0.002 & Initial pressure wave reaches core exit \\
0.007 & Costa FE thermal limit ratio reaches minimum of 3.80 \\
0.039 & Pressure sensor detects low system pressure \\
0.031 & Initial pressure wave reaches accumulators \\
0.070 & Reactor scram rods begin to insert \\
0.72 & Check-valve in makeup line completely closed \\
1.40 & Letdown valves completely closed \\
13.0 & Break flow equilibrates with accumulator flow (within 5\%) \\
750. & Accumulator flows reach zero \\
1800. & Pony motor batteries expire \\
\hline
\end{tabular}




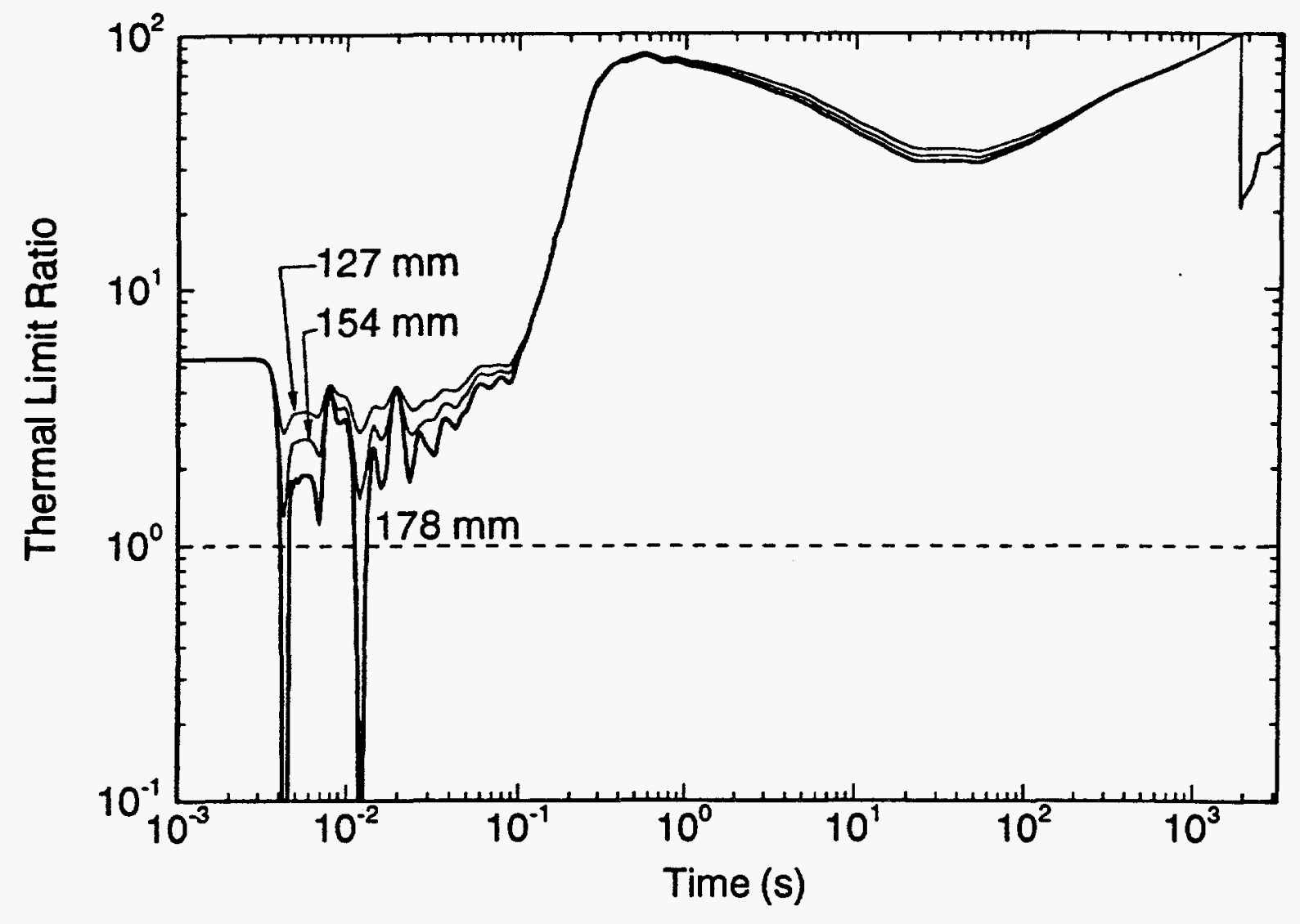

Fig. 26. FE thermal limit ratios for limiting break sizes for hot-leg breaks with coincident LOSP for the three-element-core configuration. 


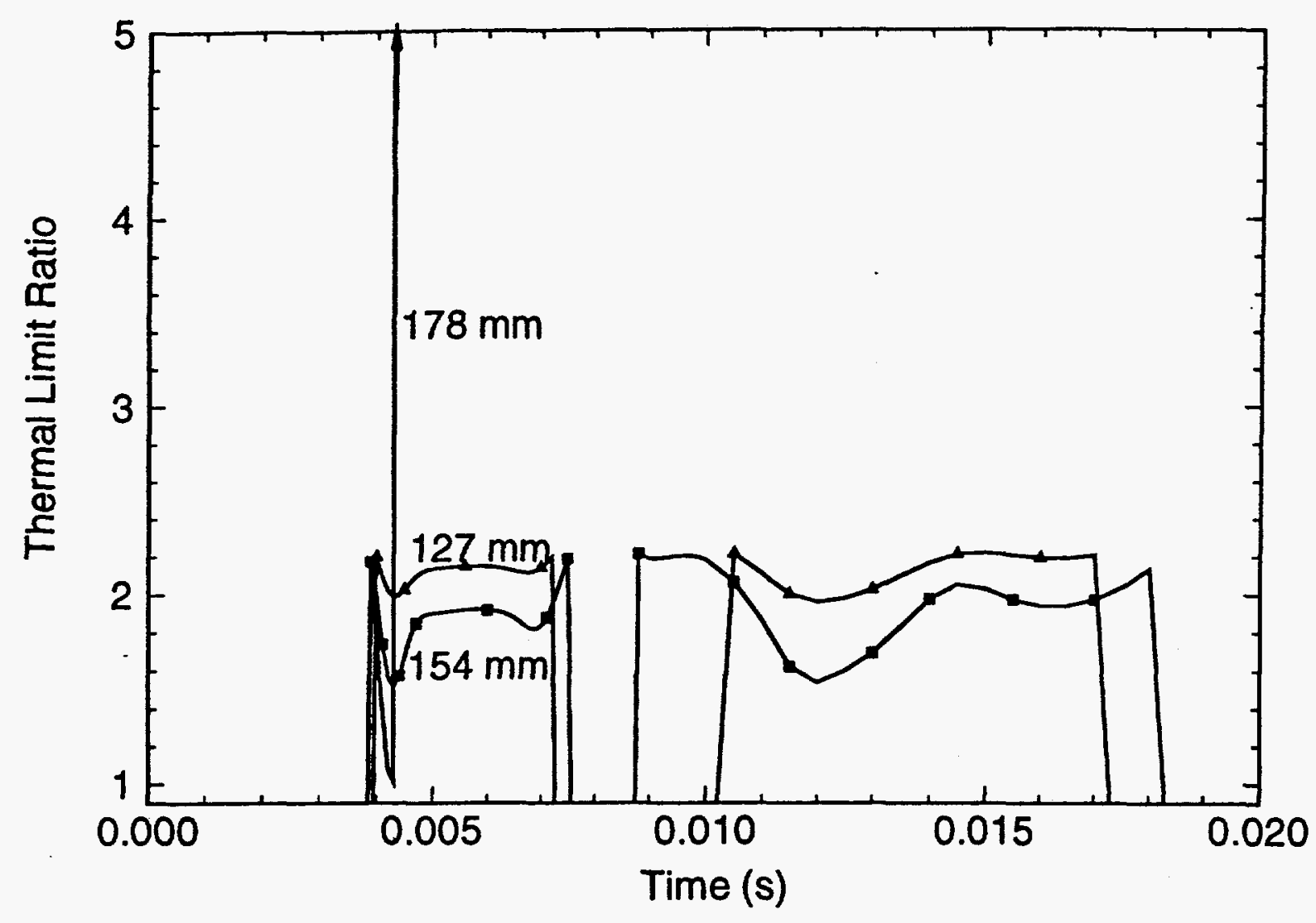

Fig. 27. CHF thermal limit ratios for limiting break sizes for hot-leg breaks with coincident LOSP for the three-element-core configuration. 


\section{REFERENCES}

1. R. M. Harrington, Oak Ridge National Laboratory, "CSAR Update on Accident Performance of TwoElement Core," Internal Correspondence, March 28, 1995.

2. N. C. J. Chen et al., RELAP5 Model for Advanced Neutron Source Reactor Thermal-Hydraulic Transients, Two-Element Core Design, ORNL/TM-13075, Lockheed Martin Energy System, Inc., Oak Ridge Natl. Lab., September 1995.

3. N. C. J. Chen et al., RELAP5 Model for Advanced Neutron Source Reactor Thermal-Hydraulic Transients, Three-Element Core Design, ORNL/TM-13076, Lockheed Martin Energy Systems, Inc., Oak Ridge Natl. Lab., September 1995.

4. D. L. Selby, ANS Monthly Progress Report for January 1995, ORNL/ANS/INT-5/V82, Martin Marietta Energy Systems, Inc., Oak Ridge Natl. Lab., January 1995.

5. R. M. Harrington, ANS Monthly Progress Report for March 1995, ORNL/ANS/INT-5/V84, Martin Marietta Energy Systems, Inc., Oak Ridge Natl. Lab., March 1995. 
ORNL/TM-13077

\section{INTERNAL DISTRIBUTION}

1. J. H. Campbell

2. N. C. J. Chen

3. K. W. Childs

4. W. G. Craddick

5. D. K. Felde

6. G. Gilliland

7. R. M. Harrington

8. D. M. Hetrick

9. M. A. Kuliasha

10. D. G. Morris

11. C. H. Shappert
12. C. D. Sulfredge

13-17. M. W. Wendel

18. P. T. Williams

19. G. L. Yoder

20. Central Research Library Document Reference Section

21. Y-12 Technical Library

22. Laboratory Records Dept.

23-24. Laboratory Records (ORNL)-RC

25. ORNL Patent Office

\section{EXTERNAL DISTRIBUTION}

26. U.S. Department of Energy, Oak Ridge Operations Office, FEDC, MS-8218, P.O. Box 2009, Oak Ridge, TN 37831-8218

27. Office of Scientific and Technical Information, P.O. Box 62, Oak Ridge, TN 37831 